Est Ag 37 (2002) 101-161

\title{
Ecología ¿ciencia o aguafiestas? (II)
}

\section{La religión pide también la palabra}

Considero que desde una visión desapasionada, era de suponer que ahora que lo ecológico está de moda, lo mismo que otros movimientos como el feminismo y el pacifismo, otros grupos e ideologías trataran de sacar partido de la situación. La religión pudiera ser uno de ellos. Es más, algunos sociólogos defienden la teoría de que el hombre necesita la religión, y que las ONG, los movimientos pacifistas y ecologistas son "una especie de sustituto de aquella". Los teólogos de la liberación, entre otros, prefieren dar un paso más, y pasar de la ecología a la teología ecológica (la eco-teología que ya hemos citado) y/o la eco-espiritualidad1. Todo lo demás sería un "miope conservacionismo y ambientalismo". Bien pudiera ser, pero -como ya he afirmado-, al menos de momento, podría bastarnos, con esto último.

. Nada diremos sobre aquellos otros que recurren a los Profetas de Israel para ver por todas partes desastre y destrucción ${ }^{2}$.

Al hablar de religión, que no pocos identifican con ideología o, al menos, como parte sustantiva de una ideología (y a ésta ya nos hemos referido), cometemos conscientemente un reduccionismo, ya que nos referimos únicamente en este trabajo al cristianismo y, más en concreto, casi exclusivamente al catolicismo, y de forma muy fragmentaria y simplemente introductoria. $Y$ al catolicismo desde la sociología y no desde la teología ${ }^{3}$. Más en concreto, no

1. La eco-teología y la eco-espiritualidad desean, en líneas generales, "vivir la experiencia religioso-espiritual desde la realidad de un cosmos habitado y asumido por Dios". Cf. V. PÉREZ PRIETO, op. cit., p. 6.

2. Jer 20,8: "Siempre que hablo, tengo que proclamar: ¡Desastre!; tengo que clamar: ¡Destrucción! La palabra del Señor se volvió para mí un escarnio, una burla continua".

3. Esto a pesar de que algunos, como James Lovelock, afirman que "Teología y ciencia (...) no están separadas, sino que forman una única línea de pensamiento" (Las edades de Gaia. Una biografia de nuestro planeta vivo, op. cit. p. 228). La cuestión ecológica es un reto a la humanidad, también a la teología de la creación y a la ética. La crisis ecológica 
nos interesa tanto el sentido en sí de los textos bíblicos y de las verdades religiosas -cuyo sentido auténtico puede haber sido redescubierto en fechas recientes-, sino, sobre todo, la forma en que esos textos o verdades fueron interpretados y vividos, y llegaron a conformar así la cultura de los pueblos (sus normas, valores y sentimientos), su conciencia histórica.

Es verdad que muchas religiones "primitivas" 4 y orientales (Hinduismo ${ }^{5}$, Budismo $^{6}$ y Taoísmo ${ }^{7}$, por ejemplo) tienen visiones más inmanentes y empáticas con la Madre Tierra y su devenir y, a veces, al menos desde la perspectiva occidental, hasta extremos que pudieran hacerlas incompatibles con unas sociedades industrializadas. Es evidente que como cristianos, es necesario que nos dejemos interrogar y fecundar por las demás tradiciones religiosas. No obstante no podemos caer en una visión demasiado ingenua; la vieja inocencia primitiva llevaba aneja a su armonía con la naturaleza una violencia dominadora en las relaciones humanas. Además, hoy no podemos pretender recuperar aquella inocencia "virgiliana". Occidentales somos ...

Los cristianos se refieren al conjunto del mundo natural con el nombre de "creación", palabra cargada de contenido, que añade al concepto de naturaleza, las resonancias de la fe bíblica en la obra creadora de Dios, del cual deriva y depende todo lo que existe. "En el principio creó Dios los cielos y la

obliga a la teología a reflexionar sobre el significado del dominio confiado por Dios al hombre en su plan creador, sobre la dimensión cósmica del pecado y la redención. "Quienes quieran hablar hoy de Dios, de manera creíble, deben obligarse en estos temas a adquirir un mínimo de conocimientos científicos". Cf. A. BEAUCHAMP, El creyente ante la creación. Ediciones Mensajero, Bilbao 1999. Ya hemos hecho referencia al cambio de la imagen del "totaliter alter" como principio de Energía o Libertad absoluta, que podría conllevar el cambio de paradigma (modelo estándar de universo en expansión).

4. Para las religiones primitivas, -en oposición a las monoteístas o religiones del libro-, el ser humano está totalmente inmerso en la naturaleza, a la que considera como algo sagrado, pues la ve marcada por lo numinoso. Según el animismo, elemento común de todas estas religiones, todo lo creado tiene un alma, una fuerza vital. La madre tierra es un organismo en el que está entretejido todo lo que existe. Cf. Concilium 261 (1995), particularmente, Sylvia Marcos, "La sacralidad de la tierra. Perspectivas mesoamericanas"; V. FERRANDEZ OBRADORS, op. cit., pp. 16-24; J. GAFO, (Dir.) voz "ecologismo y religiones", op. cit.

5. Como es sabido, la creencia en la reencarnación conduce a una particular actitud de respeto por los demás seres vivos, ya que todos están insertos en una "inseparable comunidad de destino".

6. Para Buda, lo limpio es "lo que rechazó matar lo que está vivo ... Lleno de compasión, da a todos los seres amor".

7. En las máximas de Lao Tse en el Tao te king, se afirma: "Producir y nutrir, crear sin poseer, multiplicar sin someter: ése es el misterio de la vida". 
tierra"8. "Tuyo es el cielo, tuya también la tierra, el orbe y cuanto encierra tú fundaste" $"$.

También el hombre es creado por Dios y recibe la dignidad de ser hecho a imagen y semejanza de Dios: "Y dijo Dios: Hagamos al ser humano a nuestra imagen, como semejanza nuestra"10. Dios entrega la tierra al hombre, como lo afirma con fuerza el salmista: "Los cielos son los cielos de Yahweh, la tierra se ha dado a los hijos de Adán"11. La tierra es de todos los "vivientes", y ningún individuo ni grupo humano puede arrogarse el derecho de ser poseedores exclusivos ${ }^{12}$; sobre el derecho a la propiedad privada grava una "hipoteca social", el destino universal de los bienes, como, de alguna forma, pudiera significar el año jubilar judío. El Éxodo prescribe el reposo cíclico, en cada año sabático: "Seis años sembrarás tu tierra y recogerás su producto; al séptimo la dejarás descansar y en barbecho, para que coman los pobres de tu pueblo, y lo que quede lo comerán los animales del campo. Harás lo mismo con tu viña y tu olivar"13. Y, el creyente le pide a Dios que le aleje del exceso y de las falsas necesidades: "No me des pobreza ni riqueza; -pide el sabiodéjame gustar mi bocado de pan"14.

La tierra es preludio y anticipación del don final, en el cual "esperamos, según nos lo tiene prometido, cielos nuevos y nueva tierra en la que habite la justicia"15. "Luego vi un cielo nuevo y una tierra nueva"16. La experiencia cotidiana de la Providencia de Dios y de la bendición de la tierra, hace que el hombre se sienta continuamente impulsado hacia bienes duraderos y visiones definitivas y plenificadoras.

Lynn White Jr., con su artículo "Las raíces históricas de nuestra crisis ecológica"17, publicado en la revista $S$ Sience ${ }^{18}$ y citado cientos de veces, fue

8. Gen 1,1 .

9. Sal 89,12 .

10. Gen $1,26$.

11.Sal $115,16$.

12. Gen 1,30: "También a todos los animales de la tierra, y a todas las aves del cielo, $\mathrm{y}$ a todos los vivientes que sobre la tierra están y se mueven les doy para comida cuanto de verde hierba la tierra produce. Y así fue". La Gaudium et Spes afirma: "Los bienes creados deben llegar a todos en forma equitativa, bajo la égida de la justicia y con la compañía de la caridad" (GS 69).

13. Ex 23, 10-11.

14. $\operatorname{Pr} 30,8$.

15. 2P 3, 13.

16. Ap 21, 1.

17. "The Historical Roots of our Ecological Crises". En Science 155 (III/1976) pp. 1.203-1.207). White escribe: "El cristianismo es la religión más antropocéntrica que ha exis- 
uno de los primeros en acusar a la religión cristiana de provocar el desastre ecológico con el concepto de "conquista de la naturaleza". John Passmore ${ }^{19}$ ampliaba esta responsabilidad al pensamiento judeocristiano,y otros lo extienden también al islam ${ }^{20}$-esto es, a las tres religiones del libro.

El texto del génesis: "Sed fecundos y multiplicaos y llenad la tierra y sometedla: dominad en los peces del mar, en las aves del cielo y en todo animal"21, se ha tomado, a veces, como la justificación de una actitud de dominio sobre la naturaleza en el occidente cristiano.Dios forma a los animales del barro al igual que al hombre, y éste les impone un nombre para indicar su dominio y soberanía sobre todos ellos ${ }^{22}$. Este dominio es para algunos el origen de prácticas que han conducido al deterioro de la naturaleza 23 .

Más adelante el texto bíblico dice: "Tomó Dios al hombre y le dejó en el jardín para que lo labrase y cuidase"24. Este texto parece reflejar que el hombre no es señor, sino administrador de los bienes de la tierra. Y cuando la

tido jamás en el mundo. En absoluto contraste con el viejo paganismo y las religiones asiáticas, no sólo establece un dualismo entre el hombre y la naturaleza, sino que, además, insistió en que es la voluntad de Dios que el hombre explote la naturaleza para sus propios fines".

18. La prestigiosa revista Science es el órgano de la Asociación Americana para el Avance de la Ciencia.

19. La responsabilidad del hombre frente a la naturaleza. Alianza, Madrid 1978.

20. Sobre el islamismo, puede verse la comunicación de A. Lucena al XV Congreso de Teología, Ecología y cristianismo, "La ecología y las grandes religiones".

21. Gen 1,28. Los verbos arameos correspondientes a "someter" y "dominar" pudieran contener, en el lenguaje bíblico, dos imágenes significativas. El primer verbo serviría para descubrir el dominio de un rey sabio que se ocupa de sus súbditos y hace de todo para que no les falte nada. El segundo verbo ("radah") nos remitiría a ser guía, pastor de la tierra. La facultad dada por Dios a las criaturas humanas, en ambas formulaciones, no representarían un dominio absoluto, sino relativo; como guía responsable y atento que protege lo que se le ha confiado. Así lo entiende el Papa Juan Pablo II, en la encíclica Sollicitudo Rei Socialis:" El dominio confiado al hombre por el Creador no es un poder absoluto, ni se puede hablar de libertad de 'usar y abusar', o de disponer de las cosas como mejor parezca" (SRS 34); Cf. también V. FERRANDEZ OBRADORS, op. cit., pp. 33-36.

22. Gen 2, 19-20: "Entonces el Señor Dios modeló de arcilla todas las bestias de campo y todos los pájaros del cielo y se los presentó al hombre para ver qué nombre les ponía. Y cada ser vivo llevaría el nombre que el hombre les pusiera. Así el hombre les puso nombre a todos los animales domésticos, a los pájaros del cielo y a las bestias del campo; pero no encontró ninguno como él que le ayudase".

23. En la historia cristiana ha habido una amplia tradición de desprecio del mundo, que llevó a la "fuga mundi" para llegar a un Dios espíritu puro, que Luis de Buñuel satirizó en su película "Simón del desierto".

24. Gen 2, 15 . 
Biblia afirma: "Dios vio todo lo que había hecho y era muy bueno"25, podría enviarnos un mensaje de optimismo ${ }^{26}$.

La dominación del hombre 27 sobre la tierra pudiera haberse justificado a partir de tres elementos ideológicos: la naturaleza sólo existe en beneficio del hombre; Dios es un ser totalmente transcendente que no se interesa por los elementos no humanos de su creación (la visión opuesta habla de panenteísmo) ${ }^{28}$; y concepción del mundo natural como "una esfera de profanidad", como consecuencia de la tradición dualista que contrapone la materia y el espíritu ${ }^{29}$. Estos tres elementos ideológicos nada tienen que ver con la corriente más genuina en la que no hay una concepción negativa del mundo ni de la materia: la afirmación fundamental de la fe cristiana en la encarnación de Dios en Jesús de Nazaret, el Cristo; ni tampoco con la concepción del "Cristo cósmico" de Teilhard de Chardin, que arrastra consigo hacia Dios a toda la creación hacia la plenitud final ${ }^{30}$; ni con la "intuición cosmoteándrica" -que ya anotamos- de Raimond Panikkar, una interpretación de la realidad

25. Gen 1,31. Además de los textos bíblicos citados, otros pasajes pudieran tener cierto contenido ambiental, como: Lev 25,8-12 (descanso sabático también para la tierra); Sals $8,19,65,96,104,114,147$ (alabanza a Dios de diferentes elementos de la tierra: cielos, mar, montes, collados ...); Jer 12,10-11 (clamor contra los "saqueadores de la tierra"); Dan 3,5688 (canto de alabanza de los tres jóvenes); Hch 17,28 (panenteísmo); Ef 1,3-4: ("unidad del universo, terrestre y celeste, por medio de Cristo"); Col 1,15-20 (Cristo, "primogénito de toda criatura"); Ap 21,1 ("esperamos un cielo nuevo y una tierra nueva"). Cf. VV. AA. Enciclopedia de la Biblia, Verbo Divino-San Pablo, Estella-Madrid, 1983; A. SALAS, Los orígenes. Del Edén a Babel, San Pablo, Madrid 1992.

26. A. Primavesi, hace una relectura del Génesis "de un modo no jerárquico", ecológico y a la luz de la tesis de Gaia, de la comprensión del planeta como una realidad viva. (Del Apocalipsis al Génesis. Ecología, feminismo, cristianismo. Herder, Barcelona 1995; Cf. también, AGUSTIN, "Feminismo y ecología", en Ecología y cristianismo. XV Congreso de Teología.

27. "Maître et possesseur de la nature", dijo Descartes.

28. "Todo-en-Dios". "En él [Dios] vivimos, nos movemos y existimos" (Hch 17,28), dijo san Pablo en el discurso del Areópago. "Transparencia de Dios en el Universo" (P. Teilhard de Chardin) totalmente contraria a la expresión de Jacques Monod: "El hombre está solo en un mundo ciego y sordo a sus gemidos".

29. "La pureza no consiste en la separación (entre materia y espíritu), sino en una penetración más profunda del Universo" (P.TEILHARD DE CHARDIN, "La Potencia espiritual de la materia", en Himno del Universo, Taurus, Madrid 1971, p. 64; Cf. también, del mismo autor, El medio divino, Taurus, Madrid 1967; y, Como yo creo, Taurus, Madrid 1970).

30. "Nuestra pobre e insignificante existencia forma un bloque con la inmensidad de todo lo que existe y todo cuanto deviene". (Escritos del tiempo de guerra, Taurus, Madrid, 1966, p. 37). 
que quiere englobar armónicamente el triple protagonismo del cosmos, el hombre y Dios ${ }^{31}$.

Aún dentro de esta última grandiosa concepción, no creo que podamos olvidar, como ya hemos dicho, el "principio antrópico", el hombre no es simplemente un ser más en el cosmos.

Ian Bradley ${ }^{32}$, ministro de la Iglesia de Escocia ${ }^{33}$, se muestra solidario con las críticas de los ecologistas a las iglesias, y denuncia, desde dentro, que el cristianismo ha sido cómplice de la explotación indiscriminada y abusiva de los recursos de la Tierra, porque no ha tenido suficientemente en cuenta los elementos no humanos de la creación. Según él, no es necesaria una nueva teología de la naturaleza, sino volver al mensaje original de la Biblia, tal como era entendida por la Iglesia primitiva ${ }^{34}$.

San Pablo en una de sus cartas escribía : "Pues sabemos que la creación entera hasta ahora gime y siente dolores de parto" (Rom 8, 22). Sentía por fe (no por ciencia añade Laín) ${ }^{35}$ los gemidos de parto de la creación entera que trata de liberarse de la servidumbre de la corrupción y manifestar la libertad de los hijos de Dios. El texto paulino podría reducirse a la humanidad cuyos dolores de parto liberador escucharía el hombre de fe. Pero muchos exegetas lo refieren a toda la creación; se trataría de restaurar la armonía perdida entre

31. "El principio cosmoteándrico puede expresarse diciendo que lo divino, lo humano y lo terreno, son las tres dimensiones irreductibles que constituyen lo real". (La nueva inocencia, Verbo Divino, Estella 1993, p. 55).

32. Dios es verde. Cristianismo y medio ambiente. Sal Terrae, Santander 1993. En esta obra, Bradley escribe: "La fe cristiana es intrínsecamente "verde" (...) Pero (...) necesitamos siglos de pensamiento antropocéntrico que colocaron al hombre y no a Dios, en el centro del universo y que hicieron de la Iglesia occidental una de los más importantes cómplices de la explotación indiscriminada y la contaminación de la Tierra" (p. 15).

33. En 1986, el grupo "Religion, Science and Technology", de la Iglesia de Escocia, publicó un informe ecologista titulado "Mientras dure la Tierra". Dentro de las Iglesias cristianas fue pionera una comisión de investigación de la Iglesia de Inglaterra, constituida en 1875 , que ya entonces hablaba de la necesidad de una "representación religiosa del mundo que refleje el orden común en que conviven el hombre y las demás criaturas vivas; un orden en el que puedan relacionarse mutuamente el ser humano, su trabajo y la naturaleza orgánica e inorgánica". (I. Bradley, op. cit. p. 22). El Consejo Ecuménico de las Iglesias viene promoviendo, desde hace tiempo, una reflexión sobre el ecologismo por medio de grupos de trabajo, conferencias o grandes encuentros mundiales, como las tres grandes conferencias ecuménicas: Vancouver (Canadá 1983), Basilea (Suiza 1989) y Seúl (Corea del Sur 1990); esta última recoge un decálogo de afirmaciones fundamentales. Cf. Hacia una alianza por la justicia, la paz y la salvaguardia de la creación.

34. Cf. J. GIRO, "Cristianismo y medio ambiente" (1998).

35. P. LAIN ENTRALGO, El problema de ser cristiano. Galaxia Gutenberg/Círculo de Lectores, Barcelona 1997. 
el hombre y las criaturas. Hay más textos bíblicos en favor de este sentido cósmico paulino de la redención. Ya en su libro Idea del hombre (1996), Laín radicalizando a Zubiri, interpreta la tradicional doctrina cristiana sobre su condición de imagen y semejanza de Dios, como continuador de la creación y hermano de las criaturas en un sentido más profundo aún que el franciscano "hermano sol" 36 .

Algunos Padres de la Iglesia, como, por ejemplo, san Agustín, tienen textos que pueden ser interpretados, al menos "a posteriori", como ecológicos: "Levanta la mirada de tu inteligencia; usa los ojos, como hombre, ponlos en el cielo y en la tierra, en las bellezas del firmamento, (...) en la ordenada sucesión de los tiempos: pon los ojos en las hechuras, y busca al Hacedor; mira lo que ves, y sube por ahí al que no ves"37.

En líneas generales, pudiera admitirse que los pueblos antiguos imitaban la naturaleza, los intermedios trataban de dominarla y los modernos intentan crearla ("Dolly", "Polly" y "ANDi). Y que en determinados momentos históricos (no sólo en la Edad Media), debido a una determinada interpretación de algunos textos bíblicos y a la defensa a ultranza de la trascendencia divina, la teología dominante discriminara entre Dios y su creación, siempre a favor del primero, lo que pudo conducir a determinadas visiones "espiritualistas y moralistas", a concepciones excesivamente antropocéntricas y a abominar del disfrute de lo natural.

Claro que desde una visión cuasi mística puede afirmarse también que "los clásicos elementos de la naturaleza: tierra, agua, aire y fuego han sido vistos desde los albores de la humanidad como las manifestaciones básicas de un cosmos en el que la conciencia humana ha intuido la presencia de un ser superior (...) Descubrimos al final que todo viaje por el mundo empieza y acaba en el mismo punto: Dios" 38 .

36. El cristianismo pudiera ser una religión a la vez de epifanía y de promesa. El curso de la historia, según Zubiri, es una creación de posibilidades en el mundo y de capacidades en la humanidad. Ya Ortega afirmaba que "la historia es un entusiasta ensayo de resurrección".

37. San Agustín, Serm. 123, 2, 3. En De Genesi contra manicheos I, 21, 32, el mismo Agustín escribe: " La palabra universo se deriva de la palabra unidad (...) Por eso, debemos contemplarlo en su totalidad para ver su hermosura y su unidad. Es algo así como un discurso bello, que es bello, no por cada palabra en particular, sino por todas en conjunto".

38. Cf. I. GOMEZ-ACEBEDO, (Ed.) Del cosmos a Dios. Orar con los elementos.

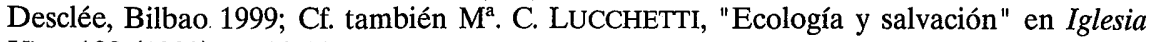
Viva, 193 (1998) pp. 29-39. 
Y también pudiera admitirse que durante la Edad Media, los monasterios unieron la explotación agrícola y ganadera con la conservación de la naturaleza de la que el cultivo del hombre era considerado como una nueva creación, y no como depredación sin control.

De todas formas, parece claro que esa especie de confraternización con todos los elementos de la naturaleza constituye una visión novedosa para la Edad Media, una nueva conciencia ${ }^{39}$. En su himno a las criaturas, san Francisco de Asís se refiere a la tierra con la conocida invocación: "Y por la hermana tierra que es toda bendición, la hermana madre tierra que da en toda ocasión las hierbas y los frutos y flores de color y nos sustenta y rige: ¡loado, mi Señor". Dentro de la Iglesia católica, al menos, se considera a san Francisco el patrono del movimiento ecologista, y así lo proclamó el Papa Juan Pablo II (29 noviembre de 1979).

Parecería, pues, que el cristianismo que alaba a Dios con san Francisco por toda la creación, debería seguir mirando a la tierra como hermana y madre ${ }^{40}$. Es más, algunos cristianos presentan a Jesús como un ecologista "avant la lettre", porque, entre otras razones peregrinas, siempre desarrolla los momentos importantes de su vida en huertos.

Aunque también pudiera acontecer que una gallina no forme gallinero, y que se tratara de movimientos elitistas y minoritarios dentro de la gran Iglesia.

Otra cuestión muy diferente es la larga y profunda reflexión que, por convicción u oportunismo, - para nuestro trabajo no tienen demasiada importancia-, la Iglesia católica ${ }^{41}$ y otras iglesias cristianas han hecho sobre el tema ecológico durante los últimos años.

Juan Pablo $\mathrm{II}^{42}$ ha situado su palabra sobre el cuidado de la Tierra en el contexto de la paz, de la "ecología humana" y de la "ecología social" del tra-

39. En la obra colectiva, dirigida por D. Hervieu-Léger, Religion et Écologie, Cerf, París 1993, se ofrece una aproximación a distintas perspectivas cristianas sobre la ecología, desde la benedictina a la ortodoxa o la adventista, hasta llegar a la visión de los nuevos movimientos ecológicos.

40. Cf. A. Udias VAllinA, "Hermana madre tierra" (1997).

41. Cf. Catecismo de la Iglesia católica. Asociación de Editores del Catecismo, Madrid 1992, Nos. 338-344; 2415-2418.

42. Ya el Papa Pablo VI había hablado del tema ecológico en sus encíclicas Populorum progressio (1967) y Octogesima adveniens (1971), así como en sendos discursos ante la FAO (1970) y la ONU (1972). Juan Pablo II, en su discurso a los agricultores en el "Jubileo 2000 del mundo agrícola" (12/XI/2000) les dijo: "La tierra ha sido confiada al hombre por Dios para que la cultivara y la custodiase. Cuando se olvida este principio, convirtiéndose en tiranos y no en custodios de la Naturaleza, ésta antes o después se rebelará". 
bajo. El 31 de abril de 1989, en su discurso en Madagascar, durante su visita apostólica, el Papa dijo: "Proteger el patrimonio forestal del globo, reaccionar contra la desertización y el empobrecimiento de los suelos, evitar la difusión de sustancias tóxicas perjudiciales para el hombre, la fauna y la vegetación; salvaguardar la atmósfera. Todos estos imperativos sólo pueden ser tomados en consideración con una cooperación activa y lúcida, para la cual las fronteras deben ser abiertas y superadas las luchas de influencia (...) Es urgente que la comunidad internacional se dote de los medios jurídicos y técnicos necesarios para garantizar la protección del medio ambiente, evitar los abusos inspirados por los que no puede dejar de ser llamado egoísmo de unos y detrimento de otros. (El hombre) es sobre todo un administrador y no un propietario que actúa a discreción. Debe trasmitir la tierra viviente y fecunda a las generaciones venideras" 43 .

La encíclica Sollicitudo rei socialis (1987) ofrece un marco histórico y social interpretativo que ayuda a situar el problema ecológico en su auténtica perspectiva. En el $n^{0} 34$, nos ofrece una "triple consideración": la naturaleza de cada ser y su mutua conexión ${ }^{44}$, la limitación de los recursos naturales no renovables ${ }^{45}$, y la calidad de la vida ${ }^{46}$.

43. Mensaje ecologista en la Jornada Mundial de la Paz, 1/I/1990: "Paz con Dios creador, paz con toda la creación". En este mensaje el Papa afirma: la paz está amenazada "por la falta del debido respeto a la naturaleza, la explotación desordenada de sus recursos y el deterioro progresivo de la calidad de vida" ( $\left.\mathrm{n}^{\circ} 1\right)$. "Es necesaria una visión global del problema, viendo el universo todo como un verdadero "cosmos" con un equilibrio que debe ser respetado" ( $\left.\mathrm{n}^{\circ} 7\right)$. "Es necesaria una responsabilidad de todos y una educación ambiental" (n' 13).

El 12 de marzo de 1999, el Papa Juan Pablo II afirmó ante un grupo de científicos que cada día "más y más gente en todo el mundo está elevando sus voces para denunciar los daños a los seres humanos, el ambiente, el clima y la agricultura en el mundo contemporáneo".

44. "(...) no se pueden utilizar impunemente las diversas categorías de seres, vivos o inanimados -animales, plantas elementos naturales-como mejor apetezca, según las propias exigencias económicas. Al contrario, conviene tener en cuenta la naturaleza de cada ser y su mutua conexión en un sistema ordenado, que es precisamente el cosmos".

45. "La segunda consideración se funda, en cambio, en la convicción, cada vez mayor también, de la limitación de los recursos naturales, algunos de los cuales no son, como suele decirse, renovables. Usarlos como si fueran inagotables, con dominio absoluto, pone en peligro su futura disponibilidad, no sólo para la generación presente, sino sobre todo para las futuras".

46. "La tercera consideración se refiere directamente a las consecuencias de un cierto tipo de desarrollo sobre la calidad de vida en zonas industrializadas. Todos sabemos que el resultado directo o indirecto de la industrialización es, cada vez más, la contaminación del ambiente, con graves consecuencias para la salud de la población". Juan Pablo II, termina el $n^{\circ} 34$ de la Sollicitudo rei socialis, haciendo una llamada a la "dimensión moral" del desarrollo humano: "Una justa concepción del desarrollo no puede prescindir de estas consi- 
En la encíclica "Centesimus Annus", después de hablar en el no 37 de la "cuestión ecológica" en términos muy parecidos a los empleados en Sollicitudo rei socialis, a la que cita, Juan Pablo II hace referencia a la "ecología humana" y a la "ecología social" del trabajo con trazos, que pudieran considerarse más bien confusos e, incluso, oportunistas, aprovechando el tirón de lo ecológico. Recientemente el Papa acaba de preguntarse "¿Podemos quedar al margen ante las perspectivas de un desequilibrio ecológico, que hace inhabitables y enemigas del hombre vasta áreas del planeta" ?47

Con la "ecología humana" 48 parece referirse a la "dimensión ética y religiosa", a la "estructura natural y moral de la que ha sido dotado" (el hombre por Dios ${ }^{49}$ ), en oposición a la estructura social ("estructuras concretas de pecado"), aunque también hace referencia explícita a los problemas urbanísticos y a la familia ("santuario de la vida"). En un reciente discurso (17/I/2001), de alguna forma contrapone una ecología "física", "atenta a tutelar el hábitat de los seres vivos", a una 'ecología humana' "que haga más digna la existencia de las criaturas, protegiendo el bien radical de la vida en todas sus fases y preparando a las futuras generaciones un ambiente que se acerque más al proyecto del Creador".

La "ecología social" del trabajo50 hacer referencia a la "alienación", cuando el hombre se convierte en un "remedio" (medio) y no en un "fin"51.

deraciones -relativas al uso de los elementos de la naturaleza, a la renovabilidad de los recursos y a las consecuencias de la industrialización desordenada-, las cuales ponen ante nuestra conciencia la dimensión moral, que debe distinguir al desarrollo". Cf. D. BETTONI, Cristianos y ciudadanos. Manual de iniciación socio-politica. Ediciones Mensajero, Bilbao 2000, págs. 212 y ss.

47. Carta Apostólica "Novo Millennio ineunte" (6/I/2001), $\mathrm{n}^{\circ} 51$ ).

48. En sociología, al hablar de ecología humana se trata de la ciencia de las relaciones entre los seres humanos y su medio ambiente.

49. "Incluso (el hombre) es para sí mismo un don de Dios y, por tanto, debe respetar la estructura natural y moral de que ha sido dotado" (...) El hombre recibe de Dios su dignidad esencial y con ella la capacidad de trascender todo ordenamiento de la sociedad hacia la verdad y el bien". ( $\left.{ }^{\circ} 38\right)$.

50. En sociología se habla de ecología cultural, entendida como el estudio de los factores sociales no económicos involucrados en las relaciones entre los seres humanos y su medio ambiente.

51. "La alienación se verifica también en el trabajo cuando se organiza de manera tal que 'maximaliza' solamente sus frutos y ganancias y no se preocupa de que el trabajador, mediante el propio trabajo, se realice como hombre, según que aumente su participación en una auténtica comunidad solidaria, o bien su aislamiento en un complejo de relaciones de exacerbada competencia y de recíproca exclusión, en la cual se considera sólo como un remedio y no como un fin" $\left(\mathrm{n}^{\circ} 41\right)$. 
El Papa habla también de la "conversión ecológica": "es necesario estimular y sostener la 'conversión ecológica', que en estos últimos decenios ha hecho a la Humanidad más sensible en relación con la catástrofe a la que se estaba encaminando" (17/I/2001).

Dentro de esta dinámica ecológica, "in crescendo" y omnicomprensiva, resulta difícil comprender que el hombre sea "la " única criatura terrestre a la que Dios ha amado por sí mismo", que ha repetido el Papa Juan Pablo II en algunas ocasiones, a no ser que se trate de una formulación, en cristiano, del "principio antrópico".

Leonardo Boff ${ }^{52}$, quizá el teólogo más conocido de la corriente de la teología de la liberación, considera que la ecología, como se entiende en los países industrializados, ofrece "soluciones miopes como el conservacionismo y el ambientalismo que no cuestionan el propio modelo de sociedad, ni los moldes de desarrollo y consumo que son los principales causantes de la crisis ecológica mundial, especialmente de las enfermedades y muerte prematura de los pobres".

Citando a Josué de Castro, Boff subraya que "el hambre es aún hoy el mayor problema ambiental" y señala que "la injusticia social, que genera violencia y miseria, es el más grave de los problemas ecológicos. ¿De qué sirve decirle a las poblaciones marginadas de los países periféricos que los alimentos deben estar libres de productos químicos si ellos no tienen qué comer?" se pregunta. Él defiende "una nueva alianza del ser humano con la naturaleza" y preconiza "una ecología social, esto es, basada en la justicia social"53.

Para la preservación de las grandes selvas tropicales, como la del Amazonas, Boff se inspira en el ecologista brasileño Chico Mendes y propone "una tecnología con la naturaleza basada en la extracción de recursos renovables".

Sobre el problema de la "mundialización", Boff observa que este fenómeno de "homogeneización del mundo de acuerdo con el modelo de los ricos" se ha agudizado a partir del colapso del socialismo. "Los ricos -afirmahan mundializado un modelo económico y social que apenas es occidental, pero que está ocupando todos los espacios, un modelo basado en la ciencia y en la técnica y han impuesto al mundo los hábitos políticos de Occidente, su relación con la naturaleza, sus valores políticos y culturales, su religión".

52. Ecología, mundialización y espiritualidad. 1993; "Religión, justicia societaria y reencantamiento de la naturaleza, en Iglesia Viva 193 (1998) pp. 7-29.

53. Cf. A. Domingo Moratalla, "La edad ecológica de la moral. De la justicia social a la responsabilidad cósmica", en Iglesia Viva 193 (1998) pp. 51-69. 
En otra de sus numerosas obras ${ }^{54}$, Boff concluye con un listado de las virtudes cardinales ecolôgicas y aprovecha el última paso de las ciencias biológicas para recuperar lo sagrado, la eco-espiritualidad. En la línea de Paracelso y Bacon, que decían que a la naturaleza sólo se la domina respetándola, Boff "salta de Gaia y la biosfera a la teosfera"55, encuentra en Noé el primer militante de Greenpeace ${ }^{56}$, propone a Cristo como el precedente máximo del ecologismo y a san Francisco en apóstol de un ecologismo "avant la lettre", lo que, para muchos, resulta excesivo.

Propone, eso sí, una teología unificada de la contestación, en la que une al clamor de los pobres el de la Tierra, agraviada por la avidez de unos pocos. El destino del planeta y el de los pobres está indisolublemente unido. Se está operando la emergencia de una conciencia ecológica, "que no solamente se detiene en la defensa del medio ambiente, porque estamos cansados del medio ambiente: queremos el ambiente entero, con el ser humano dentro" $(. . .)^{57}$.

54. Pueden verse, por ejemplo: Ecología: grito de la tierra, grito de los pobres. Trotta, Madrid 1996; Ecología solidaria, Trotta, Madrid 1996, con otros autores; Nueva Era: la civilización planetaria, desafios a la sociedad y el cristianismo, Verbo Divino, Estella 1995; La dignidad de la tierra. Ecología, mundialización, espiritualidad. La emergencia de un nuevo paradigma, Madrid 2000; Cf. también, J. J. TAMAYO, Leonado Boff, Ecología, mística y liberación. Declée, Bilbao 1999.

55. Cf. F. PARRA, "El catecismo ecológico según Boff". (1997).

56. Gen 9, 13-16: "Pondré mi arco iris en la nube y él se convertirá en una señal de la alianza entre mí y la Tierra (...) alianza eterna entre Dios y los seres vivos, con toda la carne que existe sobre la Tierra".

57. En su obra, ya citada, Ecología: grito de la Tierra, grito de los pobres, Boff desarrolla su peculiar concepto de la ecología, en donde señala que "el ser más amenazado de la naturaleza hoy en día es el pobre". La suya es una teología ecológica de la liberación, una ecología social, mental, espiritual, "una nueva relación del ser humano con la naturaleza, con la producción, con la planificación del futuro, con la calidad de vida". Trata de recuperar así, aquella alianza eterna que recoge el Génesis entre Dios y los seres vivos que pueblan la tierra. "Jamás la devastación, jamás el diluvio. Hay que rescatar ese texto porque nos hace falta una alianza nueva con la naturaleza. Es tiempo, incluso a nivel científico, de preservar la Tierra, de hacer una ciencia más benevolente". Esta sería la llave de lo que denomina "la utopía ecológica". Eso, y cambiar el antropocentrismo por el ecocentrismo. Considera -como ya hemos anotado que también hacen otros-, que la tradición judeocristiana "es cómplice de la crisis ecológica" puesto que "ha participado en la reafirmación del antropocentrismo, de la desdivinación de la naturaleza". Por ello pide "leer críticamente la tradición cristiana y rescatar las dimensiones ecológicas que existen, redescubrir "esa raíz profundamente mística, cósmica, que viene de la tradición de los monjes de Irlanda, y fundamentalmente de la tradición franciscana, que entiende todas las criaturas como hermanas y hermanos, y todo el universo como el gran cuerpo de Dios. Habría que rescatar esta tradición y hacerla vigente para que el cristianismo pueda aportar algo positivo en la salvaguardia de lo creado. Pero, para hacer eso, tiene que entonar su mea culpa". 
Dentro de la religión protestante existe también una vigorosa tendencia a "reverdecer" a Dios, para dotar de mensaje salvífico a la fe, ante la nueva conciencia que tiene la humanidad de sus responsabilidad sobre el medio ambiente 58 .

El cristianismo pudiera tener muchos que decir y, sobre todo, que hacer en el respeto y protección de la naturaleza. En primer lugar porque, como hemos recordado, ha sido acusado por no pocos intelectuales, incluso de los de dentro, de ser una de las grandes causas de la actual crisis ecológica, por su afirmación de un antropomorfismo radical y la insistencia en un cierto dualismo: vida presente como "valle de lágrimas" frente a la vida eterna, y carne frente a espíritu (con la consiguiente exaltación del espíritu y de la felicidad en la otra vida).

Pero, y es lo más importante, porque el cristianismo puede invitar a acercarse a la naturaleza con actitud reverente, desde una actitud sacramental, porque toda ella es presencia de Aquel que lo ha creado todo.

Desde una lectura ascética, la ecología pudiera considerarse como un aspecto de la ascesis cristiana. Como afirma la Conferencia Episcopal Lombarda59: "Esto debe inducir hacia un estilo de vida más sobrio, más atento al uso de ciertos bienes, más preocupado por los derroches y excesos de consumo. Si es necesario, deberíamos aceptar voluntariamente eventuales limitaciones o sobrecargas que apuntan a valores generales superiores". Esto es lo que algunos denominan la "autolimitación" o "mística del sacrificio". Con la máxima "yo y mis caprichos" es imposible poner freno a la explotación irracional de la naturaleza. Una lectura de ecología humana, quizás un poco utópica, pudiera ser: consumir menos para que todos puedan consumir lo necesario 60 .

Una renovada teología de la creación ${ }^{61}$-quizá lo que empieza a denominarse "ecología del espíritu"-, incluida alguna "mea culpa", pudiera ser el

58. Cf. I. BRADLEY, op. cit.

59. Op. cit., p. 27.

60. Cf. S. SPINSANTI, voz "Ecología. Dimensión espiritual", en Nuevo Diccionario de Espiritualidad. Paulinas, Madrid 19914.

61. Cf. A. TORRES QUEIRUGA, Recuperar la creación. Por una religión humanizado$r a$, Sal Terrae 1997. X. Chao Rego pide una "teología no sólo de la historia sino también de la naturaleza". Cf. A. TORRES QUEIRUGA (dir.), voz "Creación", en 10 palabras claves en religión. Verbo Divino, Estella 1992, pp. 146-151. Algunos piensan que se dio en Europa, "el caso de la teología liberal y la teología de la secularización; particularmente la teología existencial y psicologizante de Bultmann; o en el ámbito católico, la teología de Rahner o Schillebeeckx, muy centrada en el drama del ser humano y su relación personal con Dios, y aún la teología política de J. B. Metz". A excepción de Moltmann, E. Drewermann y, últi- 
camino adecuado para que el cristianismo recuperara o instaurara su aportación serena al compromiso ecológico. Porque, de justicia es reconocer, que pudiera no ser "raro que el teólogo se refugie en fórmulas que halaguen el espíritu del tiempo con propuestas "light" o que se dedique a parafrasear, ordenándolos con moralinas, los tópicos del humanismo o del voluntariado social" 62. Y esto, Aunque Boff, se cure en salud, y afirme que "no es una moda en la que entran los teólogos de la liberación para salvarse de alguna derrota".

No obstante, considero que pudiera ser cierto que "la ética cristiana no puede solucionar esos problemas porque la ecología, al igual que la guerra, la pobreza, las emigraciones y la violencia, no tiene solución sólo desde una perspectiva ética, sino que requiere planteamientos estructurales y políticos. Pero, a la vez, la experiencia nos dice que sin una instancia ética no se solucionan"63. Difícilmente se puede pensar que se puede resolver el problema del ambiente sin un profundo cambio cultural y sin una educación básica que forme una nueva conciencia ecológica. La ética puede poner su grano de arena importante en la dirección de un replanteamiento de la relación con la naturaleza y de la responsabilidad frente a la hermana Tierra.

En honor a la verdad, la religión y, en este caso, especialmente la católica, está siendo acusada de una "política" equivocada (por usar una palabra neutra) respecto al problema de la superpoblación o "explosión demográfica"64 con su prohibición de los métodos anticonceptivos (excepto los natura-

mamente, Pannenberg, el tema ecológico parece no tener relevancia en la teología europea. A pesar de todo Schillebeeckx y Metz firman la introducción ecologista de un magnífico monográfico de Concilium 236 (1991) que lleva por título "No hay cielo sin tierra". Cf. V. PÉREZ PRIETO, op. cit., p. 31. De J. Moltmann pueden verse: Dios en la creación, Sígueme, Salamanca 1987; La justicia crea futuro. Política de la paz y ética de la creación en un mundo amenazado, Sal Terrae, Santander 1992. De E. Drewermann, Clérigos, Trotta, Madrid 1995. De W. Pannenberg, Antropología en perspectiva teológica, Sígueme, Salamanca 1993. En el caso español: Ruíz de la Peña (Teología de la creación); Raimon Panikkar (La nueva inocencia); Xosé Chao Rego, (Na fronteira do Misterio, SEP, Vigo 1995), y (Camiño verde. Ecoloxía e Creación, Irimia, Santiago 1996), se han acercado con sensibilidad a la ecología. Torres Queiruga (Recuperar la creación. Por una religión humanizadora), reconoce que "la nueva sensibilidad ecológica cobra una importancia verdaderamente epocal", aunque no aborda propiamente este problema.

62. Cf. R. AGUIRRE, "Reivindicación de la Teología"(1997).

63. Cf. M. RUBIO CARRASCO, "Ha crecido mucho la conciencia ecológica" (1999).

64. Las predicciones no se han cumplido. Tras casi 20 años considerando que el crecimiento demográfico estaba desbocado y avanzaba a una velocidad de 90 millones de nuevos humanos por año, ahora resulta que apenas alcanza los 60 . La duplicación apocalíptica de la humanidad se retrasa hasta dentro de 60 años, es decir 20-25 más tarde de lo previsto. 
les) y, en general, su oposición al control demográfico, aunque el Concilio Vaticano II hable de la "paternidad responsable"65. Es verdad que el problema de la superpoblación, incluso en los últimos informes de la ONU66, se ha mitigado, pero sigue existiendo, y para mayor complejidad, se ubica en los países subdesarrollados. Parece que la "capacidad de sustentación" de la Tierra ${ }^{67}$ no puede superar la cota de 10.000 millones de habitantes, y en el año 2000 la humanidad ya ha llegado, al menos, a los 6.000. La solución no es fácil y no es nuestra intención, al menos de momento, abordarlo. Pero no basta con aducir que la distribución de la riqueza Norte-Sur es escandalosamente injusta, y que los países del Norte tienen que compartir los bienes con una solidaridad real, "antes que imponer a los del sur su férreo control de nacimientos por el procedimiento que sea" 68 .

Como conclusión provisional de todo lo dicho hasta el momento, podríamos preguntarnos que, si ya en tiempos de los sofistas se tenía como sólida certeza que el hombre era la medida de todas las cosas (Protágoras), ¿deberemos pasar ahora del antropocentrismo ${ }^{69}$ al ecocentrismo? Quizá sí, si den-

Las tendencias demográficas actuales son similares en todos los países, si bien los más desarrollados han alcanzado una situación caracterizada por una muy alta esperanza de vida, una fecundidad inferior al nivel de reemplazo generacional, un crecimiento cero o negativo, y un envejecimiento demográfico creciente. Los países menos desarrollados tienden también hacia ese mismo escenario, aunque tardarán algunas décadas para alcanzar los mismos niveles. La fecundidad en España es una de las más bajas del mundo, 1,2 hijos por mujer. (Cf. J. DIEZ NICOLAS, "Polémica sobre la baja fecundidad en España" (2000); COMISIÓN INDEPENDIENTE SOBRE POBLACIÓN Y CALIDAD DE VIDA, Elegir el Futuro, IEPALA Editorial, Madrid 1999; J. GAFO, (Dir.) voz "desafío demográfico".

65. Respecto a la explosión demográfica existe un amplio desacuerdo entre los planteamiento oficiales de la Iglesia católica y ciertas organizaciones internacionales y un número importante de Estados, como quedó evidenciado, por ejemplo, en la Conferencia del Cairo de 1994. Cf. R. VAllete, Catolicismo y demografía. Mensajero, Bilbao 1999.

66. Sobre todo el Informe del PNUD, 1992.

67. Cf. J. RIECHMANN, De la economía a la ecología. Trotta, Madrid 1995, pp. 19-23; M., RUBIO, "El desafío demográfico. Superpoblación y supervivencia". En Moralia 63 (1994), pp. 137-139.

Se sabe también que en los últimos cincuenta años la población mundial se ha duplicado, mientras que la producción de alimentos se ha triplicado.

68. Cf. V. PÉREZ PRIETO, op. cit., p. 15; J. VARA BAYON, "¿Por qué son pobres los pobres?" En Moralia 63 (1994).

69. La Ilustración tuvo no poco que ver con el antropocentrismo, al darle patente de corso al ser humano, máxime europeo, sobre toda la creación. Hegel llegó a afirmar: "La historia universal va de Oriente a Occidente. Europa es absolutamente el fin de la historia universal". 
tro del ecocentrismo encuadramos también al hombre con su particular "status", singular y único, en el conjunto de los seres ("principio antrópico") 70 .

Está también claro, que no debemos retroceder y permitir que el azar o la naturaleza salvaje nos gobiernen. Parafraseando a Lord Byron, se podría afirmar: "No es que ahora ame menos al hombre; es que amo más a la naturaleza".

Considero que los cristianos no tenemos nada que ver con los que -ya denominados- "verdes oscuros" o "ecologismo pazguato y de pandereta". "El medio ambiente adecuado para la vida humana -como ya hemos afirmadono es ciertamente la selva virgen, ni algún otro ecosistema espontáneamente ofrecido por las fuerzas de la naturaleza. Un medio ambiente saludable no puede menos que ser ambiente civilizado, esto es, logrado mediante la actuación del ser humano. El verdadero problema no es, pues, proteger la naturaleza de la acción humana, sino vigilar la calidad de tal acción"71.

¿Teología ecológica y eco-espiritualidad "versus" conservacionismo y ambientalismo? Ciertamente ecología, con dimensión espiritual incluida, pero con claridad epistemológica y metodológica. Ya Guillermo Ocham aconsejaba no observalo todo al mismo tiempo; lo contrario pudiera ser un rasgo del pensamiento precientífico. En este sentido, la ciencia sería una reducción útil de la realidad.

Debemos reconocer que en nuestra sociedad secularizada, la religión no lo tiene fácil. Aunque hoy día empieza a resultar anacrónico ser negador científico de Dios, y tiende a instalarse una nueva armonía entre razón analítica y razón cordial, la ciencia es la auténtica religión en que cree la inmensa mayoría de los países industrializados. Ella posee, hoy, los mayores templos, sacerdotes y ritos. Pero, incluso esta nueva fe, puede estar creando una megamaquinaria que violenta a la naturaleza entera.

Nuestro postmodernismo se caracteriza por la debilidad del pensamiento y del ser, por la disolución de la historia y el fin de los grandes relatos. Hoy se vive un nihilismo desencantado y revestido de debilidad, sin voluntad de poder, ajeno totalmente al ideal del superhombre nietzscheano. Se trata, en realidad, del drama del humanismo ateo, en buena parte construido con las aportaciones de los -llamados por Paul Ricoeur-, grandes "maestros de la sospecha" (Karl Marx, Sigmund Freud y Friedrich Nietzsche) ${ }^{72}$.

70. Cf. M. CARreIra, El hombre en el cosmos. Sal Terrae, Santander 1997.

71. Cf. CONFERENCIA EPISCOPAL LOMBARDA, op. cit., p. 30.

72. Cf. Ma L. BREY, "La sombra de Dios" (2000). 
De ese humanismo ateo habla el jesuita Henri de Lubac cuando afirma: "El hombre puede organizar la tierra sin Dios, pero sin él no puede organizarla más que contra el hombre; el humanismo que excluye a Dios es un humanismo antihumano".

\section{Incentivos económicos y protección del entorno natural}

Economistas y ecólogos intentan tender puentes entre sus respectivas disciplinas, y ya hay indicios de que, fuera del mundo académico, se están utilizando con éxito incentivos económicos para fomentar la protección del entorno natural y los "servicios" que éste proporciona a la sociedad. Estos incentivos se vuelven más eficaces a medida que los servicios naturales se hacen más escasos y, por lo tanto, más apreciados.

Quizá el ejemplo más representativo de "enriquecerse haciendo el bien" sea el ecoturismo ${ }^{73}$, un negocio que puede reportar altos beneficios invirtiendo en la conservación. Una empresa surafricana llamada "ConsCorp", por ejemplo, ha acordado con los propietarios de tierras de una localidad, devolver varios cientos de miles de hectáreas de tierra cultivable a su estadio original y poblar el territorio con animales salvajes.

Un ejemplo claro de enriquecerse haciendo el mal es el comercio ilegal de animales exóticos ${ }^{74}$. El comercio de animales y plantas protegidos es el tercer negocio ilegal más rentable en el mundo, después del narcotráfico y la venta de armas. Genera más de 2 billones de pesetas anuales en beneficio y provoca que 700 especies de fauna y flora estén a punto de extinguirse. 50.000 primates, 140.000 colmillos de marfil, 350 millones de peces tropicales y 4 millones de cactus son vendido ilegalmente en un solo año. Estas cifras, aportadas por el Fondo Mundial para La Naturaleza (WWF-Adena), son sólo una muestra del comercio internacional de especies protegidas, una de las causas más importantes de la pérdida de biodiversidad en el mundo. Cerca de 700 especies se encuentran en peligro de extinción como consecuencia directa de

73. El turismo se ha convertido en la base económico de muchos lugares, pero, a cambio, han tenido que pagar un alto precio: degradación ambiental y paisajística, una explotación incontrolada, cementación de las costas, pérdida de identidad y cultura, o una dependencia casi absoluta del turismo como fuente de recursos. Frente al ecoturismo, a este otro tipo suele denominarse turístico depredador. En España el turismo representa cerca del $10 \%$ de la actividad económica y del empleo.

74. El certificado CITES, es el único que demuestra que el ejemplar que se compra ha sido criado en cautividad con el fin de ser vendido. 
su captura y posterior comercio ilegal. Sin duda, si esas capturas se producen (sobre todo en países subdesarrollados) es porque hay demanda de seres vivos exóticos o de partes determinadas de su cuerpo (países desarrollados). El Norte comprar, el Sur suministra, como en la droga, y a la inversa que en las armas.

A esto hay que añadir que, según el servicio de defensa de la naturaleza de la Guardia Civil (SEPRONA), tres cuartas partes de los animales capturados mueren durante la operaciones de captura, transporte y comercialización, con lo que se hacen necesarias más capturas para satisfacer la demanda del mercado clandestino. El comercio de seres vivos motiva que se alteren las poblaciones, cuya disminución provoca efectos sobre otras especies al desestabilizar la cadena alimentaria y la relación entre predadores y presas.

En 1975, 21 países, entre ellos los de la UE, firmaron el Convenio Internacional de Especies Amenazadas de Fauna y Flora Silvestre (CITES). Desde entonces, el tráfico se convirtió en un delito que, según aplicación del nuevo reglamento europeo de 1997, basado en el CITES, supone penas de cárcel de hasta 6 años para los traficantes. España es junto con Argentina, Indonesia y Tailandia, uno de los países más afectados por este tráfico ilegal.

También se pueden obtener beneficios económicos cuando la conservación lleva a evitar los costes que, de otra manera, se habrían producido. Por ejemplo, proteger del desarrollo incontrolado las cuencas acuíferas, es una forma relativamente barata de proporcionar agua limpia y abundante a los usuarios que viven río abajo.

En los casos en que conservar un ecosistema tiene un incentivo económico, porque mantiene bienes y servicios con un claro valor de mercado, estos bienes y servicios tienen la propiedad de "exclusión". Sin embargo, la mayor parte de los servicios que los ecosistemas prestan a los humanos no tienen esa propiedad de exclusión, es decir, proporcionan beneficios a gente que ni siquiera es consciente de su existencia: prevención de la erosión y de las inundaciones por parte de las zonas cubiertas de vegetación, papel de las aves e insectos en el control de las plagas y en la polinización, etc. Como ejemplo más extremo de un beneficio compartido, se puede considerar la absorción de carbono que proporciona una hectárea de bosque, que beneficia a todos los humanos al compensar la emisiones de los GEI a la atmósfera ${ }^{75}$. En estos

75. Al hablar de gases de efecto invernadero nos referimos principalmente al dióxido de carbono $\left(\mathrm{CO}_{2}\right)$, pero no exclusivamente. Según lo establecido en la Cumbre de Kioto (COP3 1997) son seis los GEI: dióxido de carbono $\left(\mathrm{CO}_{2}\right): 80 \%$; Metano $\left(\mathrm{CH}_{4}\right)$ y dióxido de nitrógeno $\left(\mathrm{NO}_{2}\right)$ : $10 \%$; hidrofluorados, carburos perfluorados y hexafluoruro de azufre: 
casos, no se puede evitar que las personas obtengan los correspondientes beneficios y, por consiguiente, no es fácil conseguir que paguen por ello. En otros casos, como los derechos de pastoreo o las licencias de caza, pudieran considerarse como derechos "comercializables" a los que se adjudica un valor de mercado.

Los "cupos de emisión" de EE UU y los impuesto sobre la contaminación de los países europeos pudieran considerarse, quizá, como otros ejemplos de derechos comercializables 76 .

La colaboración de economistas y ecólogos en la investigación es un camino ya implantado para abordar problemas medioambientales como la conservación de la biodiversidad 77 , el cambio climático y la gestión de bosques $^{78}$, áreas de pesca ${ }^{79}$ y combustibles fósiles ${ }^{80}$.

$10 \%$. Los sectores que más emisiones de $\mathrm{CO}_{2}$ producen son el energético, el industrial y el del transporte. De ellos, el que más incrementará sus emisiones será el de transporte (aéreo, por carretera, ferroviaria y navegación).

76. Cf. L. GARWIN, "Ya se están utilizando incentivos económicos para proteger lo natural" (1999).

77. En diciembre de 2000 , más de un centenar de científicos, tras nueve años de trabajo, han conseguido la primera secuencia genética completa de una planta, la oruga o "arabidopsis thaliana", que tiene en su ADN 119 millones de pares de bases (30 veces menos que el genoma humano) que contienen 26.000 genes. Identificados los genes, y una vez elucidado qué función tiene cada uno, los expertos creen que podrán mejorar la calidad de los alimentos, "la biodiversidad ganará y también las técnicas de modificación genética". Aunque la pérdida de diversidad biológica ha sido un proceso natural, desde el principio de los tiempos, lo que preocupa a la ecología son los procesos agresivos humanos que conllevan la desaparición de muchas especies. De acuerdo con las últimas estimaciones científicas, el número de especies vegetales y animales distintos podría estar comprendido entre los 5 y los 30 millones, aunque tan sólo hay 1,4 millones de clases de seres vivos identificados o de los que se cuenta hoy con algún tipo de descripción. Y se calcula que cada año desaparecen de la Tierra unas 17.500 especies de animales y plantas, muchas de ellas sin que lleguen a ser conocidas por el ser humano. A largo plazo, la Agencia de Medio Ambiente norteamericana augura que la destrucción afectará en el año 2050 a casi el $40 \%$ del patrimonio natural que hoy existe.

78. Los bosques siguen bajo la amenaza de diversos frentes: la industria maderera, la expansión agrícola, la lluvia ácida, etc., que inciden negativamente en la capacidad como "sumideros de carbono". Y si las actuales extensiones de los bosques no han sido suficientes para detener la progresiva acumulación de $\mathrm{CO}_{2}$, todo parece indicar que esta situación se agravará en el futuro debido a la continua destrucción de las masas boscosas. Cf. A. CEBALlos, Plantas de nuestros campos y bosques. Madrid 1998.

79. Las pesca de arrastre, una modalidad que consiste en peinar el fondo del mar, mediante redes pelágicas arrastradas por dos barcos, prohibidas en España pero permitidas en el resto de Europa, está ocasionando graves heridas a los delfines. Más de 200 han aparecido muertos en la costa francesa de las Landas en febrero del 2000.

80. Las técnicas necesarias para incrementos de eficiencia de este tipo de combustiblès ya existen, pero su aplicación, según la ONU, están dificultada por una serie de "imperfecciones de mercado", -corregibles por los Gobiernos-, entre las que se encuentran: la 
Pero hasta hace poco, los economistas y los ecólogos, a pesar de cooperar, han tendido a seguir trabajando desde sus respectivas disciplinas, pero con una jerarquía tácita entre ambas: aquéllos conocidos como économistas de medio ambiente y recursos formulaban el problema, mientras que los ecólogos proporcionaban los datos básicos.

La economía ecológica surgió a mediados de los años ochenta, en parte debido a la sensación de que la economía medioambiental y de recursos se estaba implicando innecesariamente en problemas teóricos relativamente insignificantes ${ }^{81}$. Stephen Farber, economista de la Universidad de Pittsburg, afirmaba: "Los economistas medioambientales y de recursos se dedicarán a hacer ecuaciones diferenciales mientras el mundo se derrumba".

Había otro factor más político-profesional: un intento de los ecólogos de desempeñar un papel más importante en la elaboración del programa de investigación medioambiental/económica, junto a los economistas, en lugar de, como apunta un observador, ser sus "investigadores a sueldo" 82 .

La primera escuela, de corte más tradicional, tiene estrechos vínculos con el Instituto Beijer de Economía Ecológica de Estocolmo, fundado por la Real Academia Sueca de Ciencias en 1991, como centro de investigación "virtual" para los principales ecólogos y economistas del mundo.

La segunda escuela, más radical, gira alrededor de la Sociedad Internacional de Economía Ecológica (SIEC), cuyos 1.500 miembros tienen unos antecedentes más diversos que los integrantes del Instituto Beijer. Sólo alrededor de dos terceras partes son ecólogos y economistas; una minoría está formada por economistas ex-marxistas.

de información y preparación técnica; la incertidumbre empresarial sobre la rentabilidad de las inversiones en tecnologías de alta eficiencia; la falta de incentivos para abordarlas; que el inquilino pague la factura de la luz (en vez del propietario); y que la contaminación no vaya incluida en la factura energética.

81. Cf. R. VEROZ HERRADON, Ecología de las organizaciones. Aplicación a empresas de economía social. Córdoba 1999.

82. La industria española invierte al año unos 87.000 millones de pesetas en el medio ambiente, mientras EE UU invierte, por ejemplo, un billón. Además, para alcanzar los niveles de protección de la UE, España debería incrementar la cifra en 700.000 millones de pesetas al año, y aún así no llegaría a los niveles de resto de los Estados hasta el 2005. La facturación anual de la industria medioambiental comunitaria alcanza los 3,5 billones de pesetas, que pudo llegar a los 7,5 billones en el año 2000, y tiene una importante repercusión en el empleo, que ocupa a 3,5 millones de personas. "En España se sigue considerando el medio ambiente como un coste más que como una ventaja competitiva" (KPMG (Consultora), Empresa y Medio Ambiente 1997; Cf. J. MARTíNEZ ALIER,- K. SCHLÜPMANN: La ecología y la economía. FCE. México 1991. 
La inspiración de la SIEC tiene su origen en Herman Daly, economista del Banco Mundial, que, entre otras cosas, difundió la idea de que el período de tiempo durante el cual los recursos naturales de la Tierra se pueden consumir al ritmo actual tiene un límite, y de que este límite no está lejos. Daly cree que es necesario encontrar la forma de reducir el consumo humano -calculado según el ritmo de crecimiento económico- pero sin rebajar la calidad de vida ${ }^{83}$.

Los miembros de SIEC no comparten el optimismo de los economistas neoclásicos, según los cuales una combinación de la tecnología, regulación y mecanismos de mercado será suficiente para solventar problemas medioambientales, como la escasez de energía y alimentos ${ }^{84}$.

Un ejemplo de cómo se plantea la SIEC un problema, desde el punto de vista de la economía ecológica (modelos integrados), lo da Richard Norgaard. A la hora de evaluar la contaminación industrial ${ }^{85}$, un economista neoclásico restaría los "costes" de la contaminación (por ejemplo, en términos de cambio climático o de daños para la salud humana) de los "beneficios", calculados según la producción industrial y el empleo. El nivel sostenible de contaminación sería, por lo general, una cantidad cuyos beneficios son mayores que los costes. En cambio, Norgaard afirma que un economista ecológico tendría en cuenta elementos adicionales, como el derecho de las futuras generaciones a un derredor limpio. Esto tendría como resultado la exigencia de un nivel de contaminación inferior. No obstante, el mismo Norgaard reconoce que esta visión de la economía ecológica no está lo suficientemente desarrollada para poder ofrecer recetas para gestionar eficazmente los recursos medioambientales o para no perjudicar la calidad de vida.

A la mayoría de los miembros de la escuela de Beijer no les convencen los métodos de la SIEC, que creen carentes de rigor intelectual. La misma

83. Cf. W. G. CAMP, T. B. DAUGHERTY, Manejo de nuestros recursos naturales. Madrid 1999; P. SUBIRANA SAMITIER, Ecología para vivir mejor. Respuestas sostenibles a los retos personales y sociales. Barcelona 1999.

84. Existen programas, como Sianet, lanzado por la firma española Ingenieros Asesores, que permiten el control a distancia de emisiones atmosféricas, residuos y vertidos desde la sede central de las empresas o la propia fábrica, instalando medidores en los puntos de vertido y en las chimeneas.

85. La contaminación industrial practicamente abarca a todos los ramos de la actividad humana. Por ejemplo, a los restos de los satélites militares o civiles, máxime cuando no tienen éxito en sus lanzamientos, como ocurrió a principios de julio de 1999 con el satélite militar de comunicaciones "Rádiga-1, lanzado fallídamente desde el cosmódromo de Baikonur. Sus resto y los del cohete impulsor fueron hallados en Altái (Siberia), frontera con Kazajistán. Su caída constituye un peligro ecológico: unas 60 toneladas de combustible tóxico pueden contaminar una amplia zona. 
definición de economía ecológica, que proponen Norgaard y Costanza, como aquella que tiene como fin proporcionar una marco para la distribución equitativa de los recursos y los derechos de propiedad entre las generaciones de humanos actuales y futuras, y entre los humanos y otras especies, más bien sugiere un programa social que una disciplina académica ${ }^{86}$.

Uno de los objetivos que une a casi todas las escuelas de economía ecológica, es el de adjudicar un valor económico a los servicios medioambientales, que es una forma de centrar la atención en la importancia de la protección del medio ambiente ${ }^{87}$. Ello conlleva, de alguna forma, el deseo de desarrollar

\begin{tabular}{|l|c|}
\hline \multicolumn{2}{|c|}{ EL VALOR DE LA TIERRA } \\
\hline Servicios de & Coste en miles de millones \\
los Ecosistemas & de dólares anuales \\
\hline Regulación de gases & 1.341 \\
Regulación del clima & 684 \\
Regulación de alteraciones & 1.779 \\
Regulación del agua & 1.115 \\
Suministro de agua & 1.692 \\
Control de la erosión & 576 \\
Formación del suelo & 53 \\
Ciclo de nutrientes & 17.705 \\
Tratamiento de residuos & 2.277 \\
Polinización & 117 \\
Control biológico & 417 \\
Hábitats refugios & 124 \\
Producción de alimentos & 1.386 \\
Materias primas & 721 \\
Recursos genéticos & 79 \\
Ocio & 815 \\
Cultura & 3.015 \\
TOTAL & 33.268 \\
\hline Fuente: Adaptación de artículo de "Nature" $(15-05-1997)$ \\
\hline
\end{tabular}

86. Cf. E. MASOOD, "Ecólogos y economistas empiezan a encontrase" (1999). 87. Ver gráfico: "El valor de la tierra". 
un nuevo sistema de contabilidad nacional que abarque factores medioambientales actualmente excluidos de las definiciones de Producto Interior Bruto (PIB) ${ }^{88}$. Desde diversas perspectivas, se trata esencialmente de poner precio a los servicios ecológicos y a los recursos naturales. Actualmente -como afirma Robert Repetto, del Instituto Mundial de Recursos- "un país podría agotar sus recursos minerales, talar sus bosques, erosionar sus suelos, contaminar sus acuíferos y matar sus animales salvajes y sus peces hasta que se extingan, pero su PIB no se verá afectado cuando estos bienes desaparezcan". En su estudio de 1989 sobre Indonesia, Repetto llegaba a la conclusión de que el crecimiento del PIB corregido para reflejar la depreciación de la madera, el petróleo y los recursos del suelo, era un 3\% inferior a la cifra calculada de forma convencional de un 7,1\% entre 1971 y 1984.

Economistas ecológicos más radicales, como Herman Daly, critican la idea de que la salud económica de un país se pueda medir en término de cuánto producen sus ciudadanos. Su Indice de Bienestar Económico Sostenible utiliza medidas de producción habituales como punto de partida, pero suma el valor del trabajo doméstico no retribuido y después resta el coste del aire, el agua y la contaminación acústica, así como los costes de la disminución de los pantanos, las tierras cultivables, los recursos no renovables, los desplazamientos, la urbanización, los accidentes de tráfico y la publici$\operatorname{dad}^{89}$.

Pero, pese a todos sus atractivos intelectuales, este índice ha tenido poco éxito entre los políticos, y también ha sido duramente criticado por economistas ${ }^{90}$. Éstos desean seguir trabajando dentro de los parámetros de la economía neoclásica.

El desarrollo sostenible (sustentable) y la interdependencia entre la economía ${ }^{91}$ y el medio ambiente son conceptos que también, en los últimos años, han provocado un creciente interés entre los poderes políticos y la sociedad en general, en todo el mundo. Como "desarrollo sostenible" se entiende, en general, aquel que permite satisfacer las necesidades del presente sin negar las posibilidades de que las futuras generaciones satisfagan las suyas propias.

88. La valoración convencional del Producto Interior Buto (PIB), que se remonta a alrededor de 50 años, se obtiene sumando el total de la demanda final de bienes y servicios producidos anualmente por una nación.

89. Cf. E. M. "El "reverdecimiento del PIB" (1999).

90. Cf. R. CostanZA, "Servicios del ecosistema y el capital natural". En Nature 1998; M. TOMAN, en Ecological Economics (5, 1998), pp. 1-72.

91. Cf. S. v. HAUWERMEIREN, Manual de economía ecológica. Quito 1999. 
La denostada señora Thatcher lo sintetizó en la frase: "La tierra no puede ser Patrimonio de ninguna generación".

El debate sobre este asunto surge en los primeros años de la década de los setenta, tras las publicación por Donella H. Meadows y J. Randers del libro "Los límites del crecimiento", replicado posteriormente por H. S. D. Cole. La discusión, desarrollada y ampliada por otros muchos autores, giraba en torno a si el crecimiento económico continuo llevaba sin remedio a una degradación medioambiental y a un colapso a escala global. Finalmente, se llegó a la conclusión de que el desarrollo podía ser sostenido ilimitadamente, siempre que fuera modificado para tener en cuenta su dependencia, en última instancia, del medio ambiente.

El concepto de desarrollo sustentable quedó firmemente grabado en la agenda internacional con la publicación, en 1987, del informe "Our Common Future", de la Comisión Mundial sobre el Desarrollo y Medio Ambiente. En este documento se acepta, en principio, que los recursos de la Tierra bastan para abastecer las necesidades humanas a largo plazo, siendo los aspectos esenciales a debatir, la desigualdad en la distribución territorial de las capacidades naturales de sustentación y el análisis de uso eficaz y racional de tales recursos.

Sin embargo, aún hoy día, no existe un consenso claro sobre cómo formalizar las ideas asociadas con las "políticas sustentables". El concepto de sustentabilidad es complejo, todo el mundo está de acuerdo en apoyarlo, pero nadie alcanza a definirlo de modo consistente. Sin embargo, tras la mayoría de las definiciones, encontramos una idea generalmente aceptada, -como ya hemos anotado-,: el desarrollo sustentable debe satisfacer las necesidades del presente sin hipotecar la capacidad de las generaciones futuras de satisfacer en su momento sus propias necesidades.

La búsqueda de una definición operativa de desarrollo sostenible choca con dos problemas principales. En primer lugar, la existencia de incertidumbre sobre el futuro: desconocemos hasta qué punto la futura tecnología permitirá incrementar la eficiencia en el uso de un mismo "stock" de recursos. Y, también, el valor que las futuras generaciones otorgarán a los bienes medioambientales; si asumimos que éstos los valorarán más que nosotros, tendremos una razón adicional para ser conservadores en su uso.

En segundo lugar, la complementaridad entre los recursos medioambientales y los recursos artificiales. Utilizar como guía de sustentabilidad el mantenimiento del valor del "stock" total de capital en el tiempo es incorrecto, ya que numerosos componentes del capital medioambiental (los recursos no renovables) tienen una capacidad natural que no deber ser sobrepasada. Es por tanto necesario medir, además de ese valor del "stock" total de 
capital, una serie de indicadores sobre la sustentabilidad de tales recursos. Por otra parte, desconocemos en qué medida los recursos artificiales, desarrollados por el hombre, pueden llegar a compensar el futuro deterioro, o incluso pérdida, de los recursos naturales ${ }^{92}$.

A pesar de estas limitaciones, Herman Daly ha propuesto tres reglas para definir las políticas de sustentabilidad, i. e., los límites de insumos totales ${ }^{93}$ del crecimiento económico: que las tasas de utilización de recursos renovables (alimentos, bosques, agua, otras especies) deben producirse a ritmos menores o iguales a su tasa de regeneración natural; que las tasas de utilización de recursos no renovables (combustibles fósiles principalmente) sea la óptima hasta su agotamiento, y no excedan la tasa a la cual los sustitutivos renovables son desarrollados por el progreso tecnológico; y tercero, que las tasas de emisión de agentes contaminantes ${ }^{94}$ no excedan la capacidad de asimilación del medio ambiente.

Casi todos los expertos defienden que la sociedad está ahora usando los recursos renovables y no renovables a tasas no sostenibles. Tampoco sería sostenible el nivel de desechos producidos. Así lo asegura también el último

92. Cf. J. CARrillo Hermosilla, "Desarrollo sustentable" (2000).

93. Cf. D. H. MEADOWs, J. RANDERS, op, cit., p. 77.

94. En España se producen o utilizan 3 de los 12 contaminantes orgánicos persistentes (POP en sus siglas en inglés), cuya prohibición fue decidida en la reunión de 122 países organizada a principios de diciembre de 2000 por Naciones Unidas en Johanesburgo (Suráfrica). Estas sustancias son los PCB (policlorobifenilos, que se usan como aislante en equipos eléctricos), cuya eliminación ya está prevista por el Gobierno; y las dioxinas y furanos (residuos sin ninguna utilidad). El profesor holandés Kees Olie descubrió casualmente la dioxinas cuando analizaba las emisiones de una incineradora municipal en 1976. Este mismo año se produjo el accidente de Seveso (Italia), donde el estallido de un reactor de una fábrica de pesticidas clorados arrojó a la atmósfera kilos de estas sustancias. Eliminar al $100 \%$ estos contaminantes, que se producen en la combustión de residuos (desde vertederos hasta la quema de rastrojos), parece que es técnicamente imposible, aunque deberían emplearse inhibidores más que filtros. Los 12 POP prohibidos en Johanesburgo tienen en común, que son difíciles de destruir por medios naturales, que se desplazan con facilidad por el aire y que se acumulan en tejidos y vísceras. Además de los tres anotados, son: aldrín y dieldrín (insecticidas); hexaclorobenceno (fungicida); clordano (plaguicida); DDT; toxafeno, mirex y hectacloro (insecticidas); y endrín (pesticida). La contaminación natural nada tiene que ver con la "mineralización de la tierra" y el uso de plaguicidas (insecticidas, biocidas) en las tareas agrícolas, -que sólo han conseguido un $4 \%$ de aumento de la productividad de los suelos-, y contribuyen a la extinción de numerosas especies, a la contaminación de las aguas y al envenenamiento del ser humano. Según la Organización Mundial de la Salud la manipulación directa de los biocidas ocasiona cada año 3 millones de casos de envenenamiento y 220.000 defunciones. La Academia de las Ciencias de Estados Unidos mantiene que, 28 pesticidas de uso común, pueden provocar cáncer, y que la información sobre el $90 \%$ de los utilizados es insuficiente. A veces, la química agraria, prohibida por su letalidad en el primer mundo, se sigue exportando al tercero. 
Informe, denominado "GEO-2000", del Programa Medioambiental de la ONU (UNEP). En él se llega a la conclusión de que "el presente discurrir de las cosas es insostenible y ya no es una opción posponer los remedios por más tiempo". En 50 años la humanidad se ha multiplicado por 2,6 veces; el consumo es excesivo, incontrolado e insostenible; el impacto del uso de nitrógeno en el ecosistema, debido al indiscriminado empleo de fertilizantes, está acabando con las tierras fértiles: "estamos fertilizando la Tierra a escala global de forma experimental e incontrolada". Y esto, a pesar de que una encuesta de la Organización para la Cooperación y Desarrollo Económico (OCDE), llevada a cabo en 1987, daba cuenta de 150 casos de utilización de instrumentos económicos para proteger el derredor.

Una sociedad sostenible no significa estancada, fija o inadaptada. Por el contrario, sería una sociedad tendente al desarrollo (aspecto cualitativo) y no sólo al crecimiento (aspecto cuantitativo), capaz de cubrir las necesidades del presente sin comprometer la capacidad de las generaciones futuras.

La traducción de un consumo "sostenible" de bienes materiales y un tamaño deseable de la familia humana, podría ser la de una población global de la Tierra cercana a los 8.000 millones de personas, con un nivel de bienestar material equivalente a la de Europa en 1992.

Ruckelshaus ${ }^{95}$ señala la importancia de una tercera revolución, después de la agrícola y la industrial, la de la sostenibilidad, que pudiera apuntar a la información y a la biotecnología.

Meadows y Randers ${ }^{96}$-en la línea de Herman Daly- ofertan orientaciones para un desarrollo sostenible: información medioambiental al público y a los gobiernos, que conduzcan a la prevención de los problemas y a acelerar las respuestas; minimizar el uso de los recursos no renovables; uso de los renovables de forma que no excedan sus tasas de regeneración; uso de los recursos con una eficacia máxima de acuerdo a las posibilidades técnicas; desacelerar y eventualmente detener el crecimiento exponencial de la población humana y el capital físico. Todo ello exige un cambio y un compromiso psicológico y cultural.

El último informe de "Worldwide Fund" (Fondo Mundial para la Naturaleza-WWF-Adena en España) "Perspectivas de un planeta vivo 2000", utiliza por primera vez una medida de la presión humana sobre el ecosistema global, a la que denomina "huella ecológica". Esta huella es una estimación del consumo de alimentos, materiales y energía, en términos de áreas de tie-

95. Cf. D. H. MEADOWs, Ibid. p. 259.

96. Cf. Id. pp. 253-256. 
rra o mar biológicamente productivo, que se necesitan para producir estos recursos naturales o, en el caso de la energía, para absorber las correspondientes emisiones de dióxido de carbono.

La "huella ecológica" de cada individuo se ha estimado teniendo en cuenta seis componentes distintos: el área de cultivo necesaria para producir los alimentos que consume el individuo; el área de pastoreo para producir productos animales; el área de bosque necesario para producir madera y papel; el área que necesita el individuo para construir infraestructuras y vivir; y el área de bosques necesaria para absorber $\mathrm{CO}_{2}$.

Según el informe, la riqueza natural de los bosques, del agua dulce ${ }^{97}$ y de los ecosistemas marítimos de la Tierra han declinado en un tercio desde 1970. Destaca, además, que la superficie requerida para producir los recursos naturales consumidos por la raza humana y absorber el dióxido de carbono que emite, se ha duplicado desde 1961, y que hacia 1996 era un 30\% mayor que el área realmente disponible, lo que lleva a un agotamiento de la naturaleza. "La única manera de revertir esta peligrosa tendencia es tomar con seriedad la premisa de que los recursos naturales del planeta son limitados" -asevera Lubbers- (presidente de WWF).

El estudio de "Worldwide Fund" ha llegado a la conclusión, de que la superficie necesaria para producir los recursos naturales consumidos por un estadounidenses medio y absorber el $\mathrm{CO}_{2}$ que emite, es casi el doble de la superficie requerida por un europeo occidental y casi cinco veces la de un asiático, un africano o un latinoamericano.

En todo caso, como afirma Tamames ${ }^{98}$, "es necesario ir cambiando un orden productivista que todavía en muchos casos pretende crecer a cualquier coste y a costa de todo, así como una prevalencia de consumidores manirrotos que se resisten a poner límites a su propio derroche y al consumismo global, sin pensar para nada en ambos casos -y mucho menos con la guerra- en la ética diacrónica, a través del tiempo, que inexorablemente nos relaciona y nos responsabiliza con las generaciones venidera".

97. Además de los posibles trasvases entre cuencas hidrológicas, con los problemas ambientales que pueden ocasionar, una forma obtener agua dulce son las desaladoras. En febrero de 2001 el Ministerio de Medio Ambiente colocó la primera piedra de la que será la segunda desaladora más grande del mundo y la primera de Europa en Carboneras (Almería). Con 43 hectómetros cúbicos de capacidad de desalación, atenderá las necesidades de abastecimiento de unas 480.000 personas y cubrirá las necesidades de los cultivos bajo plástico de los Campos de Níjar. La instalación, valorada en 12.000 millones de pesetas, se adjudicó a la empresa sevillana de ingeniería Abengoa y a la eléctrica Endesa. El precio del metro cúbico de agua rondará las 60 pesetas.

98. Cf. R. TAMAMES, "El medio ambiente en tiempos de guerra" (1999). 
Creo que, al tratarse de economía, o sea de la obtención de beneficios, y mientras no sea posible recurrir, en la mayoría de los casos, a valores más elevados, la nueva divisa deberá ser, al final, el ya citado "Polluter Pays Principle" (PPP), "quien contamina paga ${ }^{99 " . ~ O ~ q u i z a ́, ~ m e j o r ~ e n ~ f o r m a ~ m a ́ s ~}$ positiva, "proteger a través del provecho". O más gráficamente, como asegura Greenpeace: las compañías eléctricas se resistieron en los primeros años al desarrollo de la energía eólica, pero después "cuando han visto que es un negocio, se han apuntado al carro". Incluso considero que, dentro de la economía neoclásica, puede empezar a afirmarse que la ecología es rentable, que lo ecológico vende.

\section{Haciendo un poco de historia}

En el año 1997 se celebraron homenajes a las tres conferencias internacionales más importantes sobre la protección y educación ambientales: Estocolmo (1972), Tbilisi (hoy Tiflis, Georgia) (1977) y Río de Janeiro (1992), que marcan la evolución del pensamiento sobre el medio. Antes de Estocolmo, los problemas ambientales ${ }^{100}$ parecían ser propios de la naturaleza. En Estocolmo se abre la polémica sobre los límites del crecimiento. Tbilisi ofrece la educación como instrumento para resolver los problemas ambienta-

99. "El que ensucia el agua, debe limpiarla a su costa y, además, debe dejar otra vez libre el manantial"; cuando Platón escribía esto en "Las Leyes", no era consciente de que estaba preenunciando el principio económico y medioambiental del "Polluter Pays Principle". Su interés era entonces, probablemente, estético. Hoy, sin embargo, esa preocupación es fundamentalmente ética y económica. La industria energética de EE UU, por el contrario, ha financiado estudios que auguran, que la reducción drástica de las emisiones de dióxido de carbono, producirán una disminución de hasta el $2 \%$ del crecimiento económico y fuertes incrementos en el precio de la gasolina. Recordemos que Estados Unidos es el primer contaminador de la atmósfera en términos absolutos y "per cápita". En forma positiva, hemos de constatar que ya empiezan a producirse las denominadas "condenas ecológicas". En septiembre de 1997, el juzgado de Manresa acordó que el ex gerente de una empresa peletera de Vic (Osona), condenado a seis meses y un día de prisión y al pago de una multa de 5,5 millones de pesetas (que ya pagó) por un delito ecológico, acuda durante dos años a clases de medio ambiente para rehabilitarse y dejar en suspenso la ejecución de la pena. En enero de 2001, el industrial tarraconense, presidente y gerente de Demimesa, ha sido condenado por el Tribunal Supremo a tres años de prisión menor y multa de cuatro millones de pesetas por arrojar vertidos contaminantes al río Anoia. Esta es la sentencia más dura dictada por delito ecológico en España, después de la de un industrial textil, que fue condenado a cuatro años.

100. Cf. J. LuIS RUBIO, "Los suelos y el problema ambiental" en Revista de Occidente 194-195 (1997), pp. 66-81. 
les. Y Río representa la asunción de que la problemática ambiental está causada por los conflictos humanos sobre el uso del territorio, y se insta y acepta la reducción de emisiones de gases contaminantes.

La Conferencia de Naciones Unidas sobre Medio Ambiente y Desarrollo de Río (1992), también denominada "I Cumbre de la Tierra", especialmente la "Agenda 21", está dirigida a los ciudadanos, mientras que las otras tenían como destinatarios a los gobiernos. La "Agenda 21" comprende muchos proyectos. Quizá el más controvertido es el de la transferencia de tecnología y -aún más importante- la financiación a los países pobres para iniciar el proceso de "desarrollo sostenible". Ni una cosa ni otra han sucedido. El famoso porcentaje de ayuda al desarrollo del 0,7\%, que se recomendó en Río, estaba situado en 1997 en un 0,27\%.

De la Cumbre de Río emanaron, además, dos tratados, la Convención sobre el Cambio Climático y la Convención sobre la Diversidad Biológica, y también, una declaración de principios, la Declaración de Río. Además, como "un acuerdo de segunda categoría", nació la Convención contra la Desertización $^{101}$.

La Convención sobre el Cambio Climático ha avanzado, aunque muy lentamente, hacia la toma de medidas concretas para paliar o evitar el calentamiento terrestre, pero en cambio, la Convención sobre Diversidad Biológica está practicamente aparcada desde su redacción. El problema que pretende encarar se muestra tan polifacético como inabarcable. Además, no tiene esta convención, al contrario que su gemela sobre cambio climático, un marco legal general para ponerla en práctica, y solamente se han logrado algunos acuerdos, como el relativo al comercio con productos biotecnológicos ${ }^{102}$.

101. Como ya sucedió con la Conferencia Mundial sobre la Desertización, celebrada en Recife (Brasil 1999), el 22 de diciembre de 2000 fracasó, sin llegar a acuerdo alguno, la IV Conferencia de la ONU contra la Desertización, celebrada en Bonn. Los países afectados aspiraban a que se concretara un plan para la aplicación de la Convención contra la Desertización (que entró en vigor en 1996), con un fondo propio dentro del "Global Envoroment Facility" (GEF), creado en 1990 entre el Programa de Ayuda al Desarrollo de la ONU y el Banco Mundial. Sólo consiguieron vagos compromisos y aplazamientos por parte de los países industrializados: La erosión del suelo y el avance de los desiertos a costa de terrenos cultivables son la causa que obliga cada año a abandonar su hogar a unos 135 millones de afectados. Este fenómeno de la degradación de la tierra afecta ya a más de un centenar de naciones.

102. Ante el rechazo social de los productos transgénicos, la biotecnología intenta centrarse en encontrar remedios biotecnológicos para descontaminar ecosistemas muy dañados, lo que se ha dado en llamar biorremediación. Desea demostrar que el árbol de los alimentos transgénicos no debe ocultar el bosque de la biotecnología y, en especial, las posibilidades de la biología molecular en favor del medio ambiente: en la recuperación de sitios 
Todos los países firmante se han comprometido a conservar sus recursos biológicos, para lo cual deben elaborar una estrategia nacional de biodiversidad, pero esto también va despacio. Estados Unidos no ha firmado esos acuerdos, ni piensa hacerlo, mientras no se modifique el principio de propiedad del material genético.

Desde que en la histórica Cumbre de Río se abrió para la firma la Convención Marco de Naciones Unidas sobre el Cambio Climático ${ }^{103}$, -un acuerdo internacional no vinculante-, 186 países la han firmado y ha sido ratificada por 155, entre ellos España. El objetivo último de la Cumbre era "lograr la estabilización de las concentraciones de los GEI en la atmósfera en un nivel que evite una interferencia peligrosa de la acción humana con el sistema climático" 104 .

Además de en otras reuniones o Asambleas Generales Extraordinarias de la ONU, como la celebrada en junio de 1997 en Nueva York, denominada "II Cumbre de la Tierra"105, casi todos los países presentes en la Cumbre de

degradados con contaminantes (arsénico en Doñana), en la regeneración de suelos (clorodioxinas), en la purificación del agua o, incluso, la purificación del aire. Eso puede hacerse mediante procedimientos no agresivos con el medioambiente, basados en catalizadores biológicos y no con procedimientos químicos. Aunque notablemente rezagada respecto a Estados Unidos, la biotecnología en Europa es clave para el desarrollo de industrias especialmente competitivas en sectores tales como productos químicos y farmacéuticos; atención a la salud, agricultura y procesos agrarios; productos de protección a las plantas, así como descontaminación, tratamiento y eliminación de residuos. Estos sectores representan ya el $9 \%$ del valor añadido bruto y el $8 \%$ de la cifra de empleo de la Unión Europea. Según los datos del informe Asebio (Asociación Española de Bioempresas), cerca de 93.000 personas, altamente cualificadas, trabajan en el sector de las Biociencias en nuestro país.

103. La Asamblea de la Organización para las Naciones Unidas (ONU) creó el Comité Intergubernamental de Negociación de la Convención Marco sobre el Cambio Climático en 1990, y fue aprobado en Nueva York.

104. El dióxido de carbono $\left(\mathrm{CO}_{2}\right.$ es el más importante de los GEI. Su concentración en la atmósfera, antes de la era industrial, era de 280 partes por millón y ahora es de 360 partes por millón. Los océanos, la atmósfera, la vegetación absorben parte del $\mathrm{CO}_{2}$. La respiración de plantas y animales y la actividad humana, máxime la industrial, liberan $\mathrm{CO}_{2}$ en el aire.

105. Del 23 al 27 de junio de 1997, los representantes de 170 países -entre ellos más de 55 jefes de Estado y de Gobierno-, se reunieron en Nueva York en la "II Cumbre de la Tierra" (o Asamblea General Extraordinaria de la ONU) con un borrador, que el Secretario de las Naciones Unidas Kofi Annan resumió: "la puesta en práctica del 'desarrollo sostenible' ha quedado por debajo de nuestras esperanzas". Se trataba de hacer un chequeo al cumplimiento de los acuerdos de la "I Cumbre de la Tierra" de Río de Janeiro de 1992, sobre todo en los Convenios sobre el cambio climático, la biodiversidad y la desertización, en un momento en que una política glozalizadora y sostenible se hace cada vez más imprescindible. Como decía un representante de Sudán, el espíritu y los compromisos de Río se han quedado en "eslóganes vacíos". Desde entonces las emisiones de dióxido de 
Río se han reunido seis veces desde 1995 en las COP (siglas en inglés de Conferencia de las Partes ${ }^{106}$ ) con un tema estrella: la reducción de los gases de "efecto invernadero". Estas cumbres se han celebrado en Berlín, Ginebra, Kioto, Buenos Aires, Bonn, La Haya y Marrakeck. La más importante, sin duda, en Kioto". A esas reuniones han acudido también decenas de organizaciones no gubernamentales (ONG), observadores y expertos ${ }^{107}$.

Berlín-COP1. Se reunió la primera Conferencia de las Partes de la Convención y se adoptó el llamado mandato de Berlín, que establecía que en la tercera COP (Kioto) se aprobaría un protocolo que desarrollase y regulase la convención de Río para que fuese efectiva.

Dentro de los "Mecanismos de flexibilidad", el comercio de emisiones ("Emission trading", (comercio de aire caliente) levantó una polvareda en esta cumbre. Si se establecen en un acuerdo internacional las cuotas de emisiones específicas de cada país, se puede comerciar con las cuotas asignadas a cada uno para que el comprador siga contaminando "en casa". Los que más interés tuvieron en poner en marcha este negocio fueron los países del este de Europa, especialmente Rusia. Y Estados Unidos estaba dispuesto a comprar. La posición de la Unión Europea era que, de existir ese comercio, su uso debería estar restringido.

La compra venta de cuotas de contaminación pudiera ser el más sucio intercambio comercial de la historia.

Ginebra-COP2. La segunda COP fue más una foro de trabajo, en el que se fue avanzando en las cuestiones que debía regular el protocolo, que de resultados notables.

carbono $\left(\mathrm{CO}_{2}\right)$ no han parado de crecer, más de 100.000 especies han desaparecido, y la convención sobre la desertificación -que sólo entró en vigor en diciembre de 1996-, finalizó su IV Conferencia en rotundo fracaso. Del 4 al 15 de septiembre de 2000 hubo otra Conferencia Internacional en Lyon (Francia). En ella algunos países trataron de incluir las reforestación de bosques antiguos, recientemente destruidos, como "sumideros" de carbono.

106. Conferencia de las Partes de la Convención Marco de las Naciones Unidas sobre Cambio Climático, es el nombre completo.

107. Cf. A. RIVERA, El cambio climático: el calentamiento de la tierra. Debate, colección Temas de Debate, 2000. Este libro trata sobre el esfuerzo internacional para poner en común los datos disponibles sobre el clima, realizar nuevos estudios y extraer conclusiones de la sucesivas reuniones de todos los países firmantes de las convenciones -en Berlín, Kioto, Buenos Aires, etc. 
Kioto-COP3. Ha sido la más célebre de las COP ${ }^{108}$, y a ella asistieron representantes de 171 países. En esta cumbre, celebrada del 1 al 10 de diciembre, de 1997 se aprobó el Protocolo de Kioto. Este documento establece que los países desarrollados deben reducir sus emisiones de gases de efecto invernadero ${ }^{109}$ en un 5,2\% ${ }^{110}$ en el periodo $2008-2012$ respecto al año base de contabilización, 1990. Los porcentajes de reducción no son iguales; así, la Unión Europea se comprometió a bajar sus emisiones en un $8 \%$ (con porcentajes diferentes de los países que la componen); para Estados Unidos se fijó una disminución de emisiones de un 7\%\%; para Japón, de un 6\%; y para Rusia, Nueva Zelanda y Ucrania, $0,0 \% 111$.

Los objetivos de Kioto parecen modestos, ya que no se proponen restaurar la situación existente antes del uso masivo de los combustibles fósiles, pero detendrían al menos una tendencia que hoy parece imparable. Y pudieran ser ambiciosos en la medida en que materializar la reducciones pactadas requiere abordar cambios profundos en la política energética, haciendo especial hincapié en el ahorro y en el uso de alternativas más limpias, en el transporte y en los modos de vida muy arraigados en los países más desarrollados, pero despilfarradores de energía. Dichos objetivo hoy (sobre todo después de La Haya) se reconocen inalcanzables.

108. También denominada III Convención de Naciones Unidas sobre el Cambio Climático.

109. Son seis, recordamos, los GEI cuya emisión intenta limitar el Protocolo de Kioto (1997), que fijó el porcentaje de contaminación de cada uno de ellos, y amplío su número de 3 a 6: dióxido de carbono $\left(\mathrm{CO}_{2}\right): 80 \%$; Metano $\left(\mathrm{CH}_{4}\right)$ y óxido nitroso $\left(\mathrm{N}_{2} \mathrm{O}\right): 10 \%$. A los que añadió: los Hidroclorofluorocarbonos (HCF), los Polifluorocarbonos (PFC) y los hexafloruros de azufre $\left(\mathrm{SE}_{6}\right): 10 \%$. Los más abundantes son el $\mathrm{CO}_{2}$, el metano, y el óxido nitroso. Los tres nuevos gases causantes del efecto invernadero, asumidos en Kioto a propuesta de EE. UU., son gases de origen industrial de nueva generación; en dos de los casos, los (HFC), y los (PFC) son gases inventados en esta década para sustituir a los clorofluorocarbonados (CFC) (combinaciones de flúor, cloro y carbono), los gases de la industria del frío, que fueron prohibidos en la Conferencia de Montreal, por perjudicar la capa de ozono. Actualmente la producción de estos dos gases es reducida, pero se podrían incrementar enormemente en los próximos años. El tercer gas, el $\left(\mathrm{SE}_{6}\right)$, se produce en el proceso de fabricación del aluminio, producto calificado por los ecologistas de "ambientalmente insostenible" por la gran cantidad de energía que se utiliza en su producción. La concentración en el aire de los tres últimos GEI es baja, pero su efecto en el calentamiento de la Tierra enorme.

110. El 5,2\% de reducción de emisiones acordado, significa dejar de emitir 700 millones de toneladas anuales de GEI. Algunos expertos consideran que "haría falta disminuir las emisiones de gases contaminantes un $80 \%$ para limitar los cambios climáticos ya en marcha". 


\begin{tabular}{|l|c|c|}
\hline \multicolumn{2}{|c|}{ Los diez países que más contaminan (1990) } \\
\hline Países & Millones de toneladas $\mathrm{CO}_{2}$ & $\%$ \\
\hline EE UU & 4.808 & \\
Antigua URSS & 3.985 & $22 \%$ \\
China & 2.238 & $18 \%$ \\
Japón & 990 & $10,3 \%$ \\
Alemania & 670 & $4,5 \%$ \\
India & 600 & $3,1 \%$ \\
Reino Unido & 559 & $2,7 \%$ \\
Polonia & 460 & $2,5 \%$ \\
Canadá & 438 & $2,1 \%$ \\
Italia & 300 & $2,0 \%$ \\
& & $1,6 \%$ \\
\hline
\end{tabular}

\begin{tabular}{|c|c|c|c|}
\hline \multicolumn{4}{|c|}{ Cuotas de emisión asignadas a algunos países } \\
\hline País & Cuota & País & Cuota \\
\hline Australia: & +8 & Lituania: & -8 \\
\hline Austria: & -8 & Mónaco: & -8 \\
\hline Bulgaria: & -8 & N. Zelanda: & 0 \\
\hline Canadá: & -6 & Noruega: & +1 \\
\hline Croacia: & -5 & Polonia: & -6 \\
\hline Rep. Checa & -8 & Rumania: & -8 \\
\hline Estonia: & -8 & Rusia: & 0 \\
\hline UE: & -8 & Eslovaquia: & -8 \\
\hline Hungría: & -6 & Eslovenia: & -8 \\
\hline Islandia: & +10 & Suiza: & -8 \\
\hline Japón: & -6 & Ucrania: & 0 \\
\hline Letonia: & 8 & EE UU: & -7 \\
\hline Liechtenstein: & -8 & & \\
\hline
\end{tabular}

111. Ver gráfico: "Cuotas de emisión asignadas a algunos países". 
En realidad, el progreso medioambiental de la tierra depende, en gran parte, de sólo ocho países. Cuatro de ellos pertenecen al mundo desarrollado del norte, y los otros cuatro forman parte del Tercer Mundo. Son: China, Estados Unidos, Brasil, Alemania, Japón, India, Indonesia y Rusia. Entre los ocho representan el $56 \%$ de la población mundial, el $59 \%$ de la producción económica, el $58 \%$ de las emisiones de carbono y el $53 \%$ de los bosques.

En la Cumbre de Kioto, la UE se estableció un Plan de Fomento de la Energías renovables que tiene como objetivo que, en el año 2010, el 12\% del total del consumo energético proviniera de las energías renovables ${ }^{112}$. Éstas suponían en 1999, el 5,8\% de media en la UE y en España un 6,3\%.

En mayo de 1999, los Quince de la Unión Europea determinaron los mecanismos flexibles para cumplir con el compromiso de Kioto -reducción de las emisiones de seis GEI, entre ellos el dióxido de carbono. La reducción debe ser real para cada país, al menos, en un 50\%, mientras que el resto se podrá lograr con la compraventa de derechos de emisión, uno de los "mecanismos de flexibilidad". Dentro de la UE, a España, por sus características medioambientales, su densidad de población y una industrialización menor que otros Estados miembros, se le permitió aumentar sus emisiones hasta el $17 \%$ en 2010. "Un vergonzoso privilegio" según Greenpeace.

\begin{tabular}{|lr|lr|}
\hline \multicolumn{4}{|c|}{$\begin{array}{l}\text { Porcentaje de variación de emisiones de CO} \\
\text { propuesta por la Comisión Europea (\%): }\end{array}$} \\
\hline & -10 & Luxemburgo: & -30 \\
Bélgica: & -25 & Holanda: & -10 \\
Dinamarca: & -25 & R. Unido: & -10 \\
Alemania: & 0 & Portugal: & +40 \\
Francia: & +30 & España: & +17 \\
Grecia: & +15 & Austria & -25 \\
Irlanda: & -7 & Finlandia: & 30 \\
Italia: & & Suecia: & +5 \\
& & & \\
\hline
\end{tabular}

112. El gobierno regional de Castilla y León quiere impulsar la energía solar para cumplir con ese plan de la UE. Para ello, la Consejería de Industria, Comercio y Turismo prevé alcanzar en el año 2011, 250.000 metros cuadrados de placas, 40.000 de los cuales deberán estar instalados en el año 2004. Si se cumple ese plan, la Comunidad habrá multi- 
En Kioto se discutieron los llamados "mecanismos de flexibilidad", -a que hemos hecho referencia-, esto es: la compraventa de cupos de emisiones de gases de efecto invernadero (GEI) ("Emission trading") entre países industrializados para cumplir las reducciones asignadas (comercio de aire caliente) ${ }^{113}$; la transferencia tecnológica ("mecanismos o sistemas de desarrollo limpio" ${ }^{114}$, ya sea entre países industrializados o entre éstos y países en desarrollo (el país donante se apunta las reducción de emisiones que se logren en el otro país); y los "sumideros" de carbono115, procedimientos para absorber los GEI de la atmósfera, como hacen los árboles al consumir carbono, por ejemplo. Con todo ello, se intentaba conseguir que el esfuerzo que cada país haga para contener las emisiones, se base principalmente en medidas de ámbito doméstico.

plicado casi por seis, en sólo 3 años, los 7.000 metros cuadrados de superficie instalada a finales de 1999.

113. El Protocolo asigna a cada país una cuota límite de contaminación y permite que los países puedan comprar y vender esas cuotas. Hay naciones como Rusia, a quien se le asignó en Kioto una cuota de 0,0 que, debido a su receso industrial (en 1996 estaba emitiendo -35,8), desea vender esos derechos y otros, como EE UU, que desea comprarlos. Con este sistema todos los gases que no se iban a emitir, otros los emitirán.

114. ¿Qué tipos de proyectos? ¿Qué tecnologías se aceptan? En reuniones precedentes algunos de los países más industrializados han llegado a proponer la construcción de centrales nucleares en el Tercer Mundo. De esta forma exportarían una tecnología muy cuestionada en Occidente y, además, se apuntarían la reducción de emisiones en su haber.

115. En el pasado, los bosques tropicales y del norte proporcionaban un inmenso "sumidero de carbono", absorbiendo el dióxido de carbono para la fotosíntesis. Las plantas utilizan la luz solar para convertir el $\mathrm{CO}_{2}$ en las moléculas de carbono contenidas en sus células y tejidos. Si los bosques se talan, estos sumideros se eliminan. En Kioto se dispuso que cada nación pudiera favorecer los "sumideros de carbono", es decir, incrementar el número de bosques con plantas que en su fotosíntesis destruyan dióxido de carbono, y restar esta cifra a la de sus emisiones. Por cada tonelada de carbono almacenada en los árboles habría una tonelada extra de combustible fósil que se puede quemar. El problema es que, el $\mathrm{CO}_{2}$ así almacenado, puede liberarse a la atmósfera a través de los incendios forestales. Sería, en todo caso, dejar una hipoteca para las generaciones venideras. "Plantar árboles sólo permite ganar tiempo". Actualmente existen muchas dudas entre los expertos sobre el papel de los "sumideros" en la absorción del $\mathrm{CO}_{2}$ para la fotosíntesis. La muerte y descomposición de las plantas en los bosques y en otras regiones con vegetación vuelve a liberar el carbono al aire, con lo que en los fríos ecosistemas de la tundra de Alaska y Siberia, la liberación de carbono resultante de la descomposición, puede sobrepasar la absorción atribuible a la fotosíntesis. Así lo afirma Walter Oechel, de la Universidad Estatal de San Diego. En un experimento de modelización del clima futuro, los científicos del Centro Harley han estudiado el efecto de plantar bosques de coníferas (árboles de hoja perenne oscura) en las regiones situadas por encima de 30 grados de latitud Norte, y han comparado los resultados con la situación que se crearía si esas zonas se utilizan para cultivos agrícolas. Los bosques, al ser oscuros, reflejan menos radiación solar que los campos de cultivo, sobre todo si éstos se cubren de nieve. En latitudes altas como Canadá o Siberia, la nieve cubre el suelo durante una parte importante del año; en los suelos desbrozados para la agri- 
Estos mecanismos de flexibilidad fueron uno de los principales desacuerdos entre Estados Unidos y la UE. "EE UU está a favor de ese comercio de emisiones, con las mínimas restricciones". La posición europea ("burbuja comunitaria", "Bubble") es que el uso de esos llamados mecanismos deben estar restringidos, "de modo que sólo el 50\% de la reducción que debe hacer cada país pueda cubrirse con ellos". Después de tantas discusiones, la "emission trading" se aprobó finalmente en Kioto sin ninguna clara limitación.

Otra espinosa cuestión pendiente, fue el compromiso de los países en vías de desarrollo, exentos de asumir porcentajes de reducción de emisiones. Mientras que EE UU insistía en que dichos países, sobre todo China ${ }^{116}$, India y Brasil, debían comprometerse en el esfuerzo de limitación de emisiones, el G-77, que agrupa a las naciones en vías de desarrollo, rechazaron esa pretensión y reclamaron su derecho a usar determinadas energías para favorecer su progreso económico, tal como han hecho los países industrializados a lo largo de los últimos 150 años.

Otra gran línea de debate -sin llegar a acuerdos concretos- se centró en torno a la creación de un fondo adicional para ayudar financiera y tecnológicamente a los países en desarrollo -que pretendían toda la ayuda posible-, al régimen de control y a las sanciones que se podrían imponer a los países que no cumplieran los compromisos asumidos en el Protocolo de Kioto.

Para que este Protocolo entrara en vigor (sea vinculante) es necesario que lo firmen y ratifiquen al menos 55 países cuyas emisiones supongan, como mínimo, el 55\% del total mundial. En el caso de Estados Unidos, el entonces vicepresidente $\mathrm{Al}$ Gore, ya indicó que no someterá al Senado su ratificación

cultura, la nieve puede formar un manto blanco resplandeciente e intacto, que no se produce en las regiones boscosas. El resplandor del suelo refleja la luz del sol hacia el espacio, mientras que un suelo más oscuro -el de los bosques- la absorbe y calienta. La conclusión de Richard Betts ("Nature", 9 de noviembre-2000) es que, en algunas regiones, los efectos de calentamiento global de la disminución del resplandor sobrepasarán el efecto de enfriamiento global de la absorción de carbono (fotosíntesis), si el suelo agrícola se sustituye por bosques. De modo que la deforestación-reforestación pueden ser "malas" para el cambio climático, dependiendo, al parecer, del lugar donde se produzcan. En conclusión, "en muchas áreas, los beneficios climáticos de plantar más árboles no serán tan grandes como sugiere su potencial de sumideros de carbono", afirman los investigadores de Hadley. Quizá el mayor "sumidero" de $\mathrm{CO}_{2}$ está constituido por la capacidad fotosintética y depuradora de plancton marino. Pero los millones de toneladas (unos cuatro millones) de petróleo vertidas en los océanos empequeñecen esta capacidad.

116. China parece destinada a encabezar la clasificación de países contaminantes en el año 2020. 
hasta que los países en desarrollo acepten tomar medidas sectoriales contra el calentamiento global117.

Desde nuestro punto de vista, los diez mil delegados asistentes a la Cumbre de Kioto, tras varios días de debates y controversias, decidieron aceptar algo tan a primera vista elemental, pero de suma importancia: la ciencia es creíble. El Panel Intergubernamental sobre Cambio Climático (IPPC), conformado por más de dos mil científicos de todo el mundo, elaboró en 1996 un informe en el que se demostraba y valoraba el calentamiento de la Tierra ${ }^{118} \mathrm{y}$ se concluía que una de las causas, era la actividad humana. La ciencia indica, cada vez con menos margen para la incertidumbre, que la influencia humanan en el clima mundial es perceptible y tiende a aumentar, siendo previsibles variaciones significativas en las temperaturas y en los ciclos hidrológicos del Planeta. El reconocimiento de que el problema existe, y que es necesario limitar las emisiones de una serie de gases -especialmente el dióxido de carbonoque lo producen, es un hecho cuya trascendencia no cabe velar ${ }^{119}$. El mismo Clinton, reconoció por primera vez, que "la ciencia es clara y contundente: los humanos estamos cambiando el clima global; la concentración de gases de invernadero en la atmósfera está en sus mayores niveles desde hace 200.000 años y crece significativamente".

En la ciudad japonesa se llegó a un acuerdo, cuyos objetivos pueden parecer modestos, pero que marcó un precedente histórico, al obligar a los países firmantes a tomar medidas para reducir las emisiones de gases causantes del efecto invernadero.

El resultado de la cumbre de Kioto (1997) consiente ya, desde la reflexión desapasionada, una sensación de esperanza, una lectura positiva de lo que allí sucedió. En Kioto se alcanzó un acuerdo de mínimos sobre la reduc-

117. Gobiernos como Estados Unidos, el país más contaminante del planeta con el $25 \%$ de las emisiones de dióxido de carbono, temen aplicar medidas para controlar las emisiones contaminantes, ya que supondría enfrentarse a una sociedad altamente consumidora de recursos energético con grandes corporaciones del sector de la energía.

118. 1990 ha sido la década más cálida desde 1861 de acuerdo con el tercer informe de IPCC, y parece que 1998 fue el año más caluroso del siglo.

119. El ecólogo J. Araújo considera que "aunque la ciencia ha jugado un papel estelar en el camino a Kioto, quizá el aspecto más relevante de lo acontecido a lo largo de la negociación, sea el conato de divorcio entre la razón económica y la científica, antes tantas veces abrazadas (...) porque los científicos, no los sentimentales de lo espontáneo, han identificado esa voracidad insaciable de energía, muy por encima de lo necesario y estimulada hasta que se ha convertido en modelo de conducta (...) En Kioto ha comenzado a agrandarse la fisura entre conocimiento racional y mercado (...) El aire al menos cuenta desde ahora, entre sus aliados, con las mejores mentes del planeta". ("Planeta escalfado" (1997). 
ción de los GEI, pero llegar a ese planteamiento común ya supone una toma de conciencia importante, y se convierte en el primer marco jurídico para la disminución de las emisiones de los gases que producen el calentamiento de la tierra. Pese a ser un acuerdo de mínimos, es el compromiso multinacional más importante sobre medio ambiente que se ha tomado hasta ahora en el mundo.

La importancia del Protocolo estriba en que supone una señal de salida para que los políticos empiecen a tomar medidas que deben ser mucho más ambiciosas.

Buenos Aires-COP4. Es más conocida como cumbre de Buenos Aires y se celebró del 2 al 13 de noviembre de 1998. Con la presencia de representantes de 180 países se abordó el desarrollo del reglamento del Protocolo de Kioto para su posible entrada en vigor, así como las medidas concretas que cada país debería tomar con vistas a alcanzar la tasa de reducción que le corresponda, pero se avanzó poco. De la cumbre salió el llamado Mandato de Buenos Aires, para que en la COP6 (La Haya-2000) quedasen establecidas las regulaciones del Protocolo para su ratificación.

En todo caso, las reuniones de Río-92, Kioto (1997) y Buenos Aires (1998), han demostrado como, incluso en un tema tan polémico como el cambio climático, la potencia (EE UU) que solamente con un $4,5 \%$ de la población mundial genera casi el $25 \%$ del $\mathrm{CO}_{2}$, tiene que avenirse a una cierta disciplina en el medio plazo, para frenar el calentamiento global y todas sus consecuencias, que no reconocen fronteras ${ }^{120}$.

Bonn-COP5. Representantes de 178 países, más la UE, se reunieron en Bonn, desde el 25 de octubre al 5 de noviembre de 1999, para intentar avanzar en las negociaciones de las medidas concretas sobre el calentamiento de la Tierra, contenidas en el Protocolo de Kioto. Los delegados afrontaron fuertes desavenencias, sobre todo entre Estados Unidos y la "burbuja comunitaria" (Unión Europea), puesto que en la cumbre anterior de Buenos Aires (1998), se había aprobado el plazo límite del año 2000 para zanjar los puntos

120. Los países desarrollados (del Norte) envían a la atmósfera el $75 \%$ de dióxido de carbono, mientras que los pobres sólo son responsables del 25\%. Algunos científicos han anunciado que en un futuro cercano -previsto para el año 2037- los países ricos y los países pobres contaminarán por igual. En todo caso, eso representará que el $20 \%$ de la población estará contaminado tanto como el $80 \%$. 
más espinosos. En esta cumbre se lanzó la idea, con un notable apoyo, de que dicho documento entrase en vigor en 2002 , coincidiendo con el décimo aniversario de la Cumbre de Río ${ }^{121}$.

"El cambio climático supone aumento de las temperaturas, subida del nivel del mar, alteraciones en las precipitaciones y mayor intensidad de acontecimientos meteorológico extremos; las implicaciones clave afectan a la salud humana, a la agricultura, a los bosques, a las reservas de agua y a los ecosistemas", resumió en la Conferencia de Bonn, Robert Warson, director del "Intergovernmental Panel on Climate Change" de la ONU (IPCC).

Además, a medida que se acelera el calentamiento del planeta, las plantas y animales se verán sometidos a una creciente presión para emigrar, con el fin de encontrar sus nuevos hábitats adaptados a sus condiciones de vida. Muchos no serán capaces de moverse con la rapidez suficiente. En algunas

121. El prestigioso Centro Hadley británico, presentó en esta cumbre de Bonn, los últimos resultados de su estudio. Para precisar el impacto y plazos temporales del cambio climático, este centro posee unos potentes modelos informáticos que permiten simular matemáticamente el sistema climático, es decir, las interacciones físicas, los procesos químicos y algunos biológicos que rigen su dinámica. Tan complejos son estos modelos que las supercomputadoras más potentes tardan seis meses de cálculo ininterrumpido para simular 250 años de evolución climática. Este centro, que ha conseguido hacer avanzar la evolución climática varias décadas y siglos en sus supercomputadoras, se ha planteado varios supuestos o escenarios, en los que se consideran tres situaciones: que las emisiones sigan creciendo como hasta ahora sin ninguna medida de contención; que se tomen medidas de mitigación de manera que las emisiones de $\mathrm{CO}_{2}$ se estabilicen en torno a 550 partes por millón en volumen de la atmósfera (ppmv), casi el doble de la situación preindustrial (en 1850 era de 280 ppmv); y que se estabilicen en 750 ppmv de $\mathrm{CO}_{2}$ (La concentración de dióxido de carbono en la atmósfera ha pasado de 316,8 ppmv en 1960 a 366,7 en 1998). En el primer caso (si no se hace nada): la temperatura media global en el año 2080 será $3^{\circ} \mathrm{C}$ superior a la actual, calentándose la tierra el doble de rápido que el océano. En el 2050 la subida sería de $2^{\circ} \mathrm{C}$. En el escenario de estabilización a $550 \mathrm{ppmv}$, esos dos grados se alcanzarán cien años más tarde; y en el escenario de 750 ppmv, sólo medio siglo más tarde. La contención de emisiones no tiene igual efecto en todas las repercusiones previstas del cambio climático. La escasez de agua será en el 2080, mayor que ahora para mil millones de personas en el escenario 550 ppmv, mientras que si no se hace nada o poco, serán 3.000 millones de afectados. En cuanto a la salud, los expertos de Hadley calculan que en el 2080, 290 millones de personas más que en la actualidad correrán riesgo de sufrir malaria en el peor de los casos, mientras que en los dos supuestos de estabilización de emisiones, la cifra baja a 255 y 175 millones respectivamente. Los escenarios de contención de las emisiones estabilizan el clima y los impactos a largo plazo, excepto la subida del nivel del mar, debido a su inercia térmica, i.e., al hecho de que el calor tarda en ir penetrando profundamente en las aguas y su efecto, una vez desencadenado el calentamiento, se mantiene mucho tiempo. Por ello la subida del nivel del océano -debida a la expansión del agua y al deshielo continental y ártico- es el aspecto en que menos incidencia tiene a corto plazo la atenuación del cambio climático. Las predicciones indican que el mar subirá 40 centímetros en el 2080 en el escenario de aumento libre de emisiones, y 30 y 27 centímetros en los otros dos supuestos. 
regiones, las plantas deberían trasladarse diez veces más rápido que durante la última glaciación para poder sobrevivir. Muy probablemente, el cambio climático acarreará la extinción de muchos animales y plantas ${ }^{122}$.

Por otro lado, los 11 países exportadores de petróleo ${ }^{123}$ de la OPEP hicieron piña en Bonn en torno a la reivindicación de compensaciones económicas por el empobrecimiento que significaría para ellos, aducían, un acuerdo de contención de emisiones, que supondría menores exportaciones de crudo para países con políticas de reducción de consumo de combustibles fósiles.

La Haya-COP6. A esta cumbre, celebrada entre los días 13 y 24 de noviembre de 2000 (se prolongó hasta el día 25, para intentar llegar a acuerdos de última hora) asistieron delegados de 180 países $^{124}$ con el mismo objetivo de anteriores reuniones: contener la emisiones de los GEI que provocan el calentamiento global. El éxito de la reunión se debería medir por la pronta entrada en vigor del Protocolo de Kioto. A finales del año 2000, este

122. Cf. WORLD WILDLIFE FOUND/ADENA, "Declive de la biodiversidad Terrestre por el cambio climático" (2000). Como ya afirmamos, el éxito o fracaso de cualquier especie sobre la Tierra -quizá a excepción del hombre-depende, casi en exclusiva de su capacidad de adaptación al medio que le rodea. Los animales que viven en un clima frío, por ejemplo, cubren sus cuerpos de pelo o de grasa; los que prefieren la noche desarrollan al máximo la vista; los que son excesivamente lentos o débiles se mimetizan hasta confundirse con su entorno o se disfrazan simulando una peligrosidad que no existe, etc. Todas estas adaptaciones, sin embargo, no son algo automático, sino el resultado de un largo proceso que requiere tiempo, mucho tiempo. Si el medio ambiente cambia de una forma demasiado rápida, no hay elección: las especies, incapaces de adaptarse, desaparecen si remedio. La extinción de los dinosaurios, hace sesenta y cinco millones de años, es sólo el más conocido de estos trágicos episodios que sacuden la Tierra cada cierto tiempo.

Otra actividad, directamente ligada a la actividad humana, y causa de mortandad de especies, incluso amenazadas de extinción (águila imperial, buitre negro, alimoche, quebrantahuesos, oso pardo), son los cebos envenenados. Entre 1990 y 2000 se hallaron 5.000 animales envenenados, según datos del Ministerio de Medio Ambiente, aunque el número pudiera ser mucho mayor, ya que al parecer sólo se encuentra uno de cada diez animales envenenados. La mayoría de ellos pertenecen a especies incluidas en el Catálogo Nacional de Especies Amenazadas. El uso ilegal de estos cebos tienen lugar principalmente en fincas de caza, especialmente de caza menor, para reducir el número de algunos predadores naturales. Cf. R. GRANDE DEL BRIO, El lobo ibérico. Biología, ecología y comportamiento. Salamanca 2000.

123. En la última minicrisis por el aumento internacional de los precios del petróleo, se ha tratado de justificar el rechazo de las rebajas fiscales de los precios de las gasolinas, en razones de "sostenibilidad ambiental" -se usará menos el coche si la gasolina es más cara-.

124. En La Laya se reunieron 2.000 delegados gubernamentales, 3.500 observadores científicos e industriales, ante la presencia de más de 500 periodistas. 
Protocolo ha sido firmado por 84 países -ninguno de ellos del grupo de los desarrollados- y ha sido ratificado por 22. Los quince miembros de la UE quieren firmarlo todos a la vez y cuanto antes, a ser posible en el plazo de dos años (año 2002), al cumplirse -como ya hemos dicho-el décimo aniversario de la Cumbre de Río.

Con los científicos cada vez más convencidos de que ya estamos presenciando los efectos del calentamiento global, se debería asegurar que en la próxima década habrá progresos reales en las reducciones de emisiones. Los expertos consideraban que si en La Haya no se alcanzaban acuerdos que despejasen el camino hacia la ratificación del Protocolo de Kioto cuanto antes, todo el proceso internacional sufriría, cuando menos, un nefasto retraso.

Miles de científicos, que trabajan en el IPCC, adelantaron, ante la conferencia de La Haya, un resumen de lo que serían las conclusiones de su tercer informe ${ }^{125}$. De acuerdo con este adelanto (confirmado en la presentación oficial del informe), la temperatura media global de la superficie se ha incrementado en unos 0,6 grados en el último siglo -es decir, 0,15 grados más de los estimados en el segunto informe-; el aumento de la temperatura media de la Tierra entre 1990 y 2100 será entre 1,4 y $5,8^{\circ} \mathrm{C}$-frente al 1,5 y $3,5 \mathrm{del}$ Informe de 1995-, el más rápido registrado en los últimos 10.000 años ${ }^{126}$. El nivel medio de los océanos ${ }^{127}$ subirá entre 0,09 y 0,88 metros entre 1990 y

125. Este resumen fue publicado por la revista New Scientist. Como ya hemos dicho, el tercer informe, de unas 1.000 páginas, se hizo público el 22 de enero de 2001, con el título Cambio climático 2001: impactos, adaptación y vulnerabilidad.

126. Este alza de la temperatura será un $40 \%$ superior a la media en América del Norte y en el norte y centro de Asia. Otros datos que aporta este tercer informe son: la cubierta de nieve y hielo ha disminuido en un $10 \%$ desde finales de los sesenta. También es muy probable que los ríos y lagos del hemisferio Norte pasen helados dos semanas menos ahora que a principios del siglo XX. Igualmente, se observa una reducción de los glaciares a lo largo del siglo. El nivel medio del mar ha crecido en el mismo período entre 0,1 y 0,2 metros. También se registran cambios en el régimen de lluvias, en la cubierta de las nubes y en el patrón de ocurrencia de fenómenos como la corriente cálida de El Niño, que se ha vuelto más frecuente. "La concentración atmosféricas de dióxido de carbono se ha incrementado en un $31 \%$ desde 1750 . Este nivel no se ha superado en los últimos 420.000 años, y probablemente tampoco en los últimos 20 millones de años", afirman los autores. Un tercio de las emisiones de $\mathrm{CO}_{2}$ debidas a la actividad humana se atribuyen a la quema de combustibles fósiles, y el resto a la deforestación. Todos estos datos parecen confirmar que los efectos del cambio climático, debido a factores antropogénicos y naturales, son ya perceptibles y se deben, en buena medida, a la actividad humana.

127. Esta elevación se deberá a la reducción de los casquetes polares y los glaciares. En las últimas cuatro décadas, los hielos del Océano Artico han reducido su espesor en un $40 \%$, y en los próximos cien años se calcula que pueden desaparecer entre un tercio y la mitad de los glaciares montañosos. 
2100 , frente a los 10 y 20 centímetros del siglo $\mathrm{XX}$, lo que significa un ritmo 10 veces superior a la media de los tres últimos milenios ${ }^{128}$.

En lo que respecta a la UE, el cambio climático "tenderá a extender las alteraciones que se registran en Europa". Los veranos serán más secos en el Sur, y los inviernos más húmedos en el Norte. En España, los veranos tórridos serán cinco veces más frecuente que ahora en el sur dentro de 20 años, mientras los inviernos fríos se reducirán a la mitad para esas fechas, y habrán prácticamente desaparecido hacia el $2080^{129}$.

Aunque el clima sufre una variabilidad natural, el IPCC afirma que el aumento brusco de la temperatura se debe, en parte, al incremento de las concentraciones de los GEI en la atmósfera -sobre todo el dióxido de carbono cuya concentración ha aumentado en un 30\% en los últimos 150 años-debido a la actividad industrial y agrícola ${ }^{130}$.

Estos datos corroboran los contenidos en un estudio de la Unidad de Investigación del Clima de la Universidad de "East Anglia" de Gran Bretaña, que ha elaborado un posible escenario ante el aumento de las temperaturas y sus consecuencias globales. Un apartado del mismo evalúa la situación en la

128. Según el Programa de Naciones Unidas para el Medio Ambiente (PNUMA), la subida del nivel del mar podría amenazar una superficie de unos 5 millones de kilómetros cuadrados, donde viven 1.000 millones de personas (en especial Bangladesh y naciones isleñas como las Maldivas o la Micronesia), y haría desaparecer un tercio de la superficie agrícola.

129. El primer informe de la Unión Europea -reciéntemente publicado- sobre el impacto del cambio climático en el continente europeo, parece confirmar el resumen de las conclusiones del IPCC. El informe de la UE afirma que el cambio climático será mayor en el sur de Europa que en el norte, y España, especialmente la zona meridional, sufrirá dentro de 20 años escasez de agua y desertización. En el norte del continente, sin embargo, los inviernos será más húmedos. Entre las alteraciones climáticas que se esperan para las próximas décadas en el continente, destacan el agravamiento de los fenómenos extremos (inundaciones y tormentas fuertes), la escasez de agua y el aumento de los incendios forestales en las regiones meridionales. "Las situaciones meteorológicas extremas tienen un impacto importante en nuestras sociedades y sectores como el transporte, el turismo, la energía y otras industrias encararán cambios en la demanda y en las oportunidades de mercado" -dice el informe-. En cuanto al calentamiento, las predicciones de los científicos apuntan a que aumentará la temperatura media entre 0,1 y $0,4^{\circ} \mathrm{C}$ por década. También es probable que el cambio climático provoque cambios en la fauna que afecten a la biodiversidad. El estudio, realizado por un treintena de científicos líderes de programas de investigación y revisado por 20 expertos, hace cerca de 50 recomendaciones a los responsables políticos, sobre las medidas más adecuadas que se deben tomar para hacer frente a este fenómeno. Entre las medidas propuestas figuran las estrategias para ahorrar agua en las zonas que pueden sufrir más sequía, como España, o la prohibición de construir en sitios susceptibles de sufrir inundaciones.

130. Recordemos que, como ya hemos dicho, la concentración de dióxido de carbono en la atmósfera ha pasado de 316,8 partes por millón en 1960 a 366,7 en 1998 . 
Península Ibérica, y concluye que España pudiera ser uno de los países más afectados por el cambio climático que se avecina para el siglo XXI.

El estudio de "East Anglia", que ha sido dado a conocer por el Fondo Mundial de la Naturaleza (WWF/Adena), contempla cuatro posibles escenarios, desde los presagios más graves a los más suaves. En el peor de los casos, en lo que respecta a España, la temperatura podría llegar a subir $6^{\circ} \mathrm{C}$ para el 2080 en Andalucía oriental; las precipitaciones disminuirían entre el $5 \%$ y el $15 \%$; los inviernos serían más húmedos, mientras que las otras estaciones serían más secas; el nivel del mar en las costas podrían subir entre 20 y 110 centímetros al final de la próxima centuria, inundando lugares como Doñana ${ }^{131}$, la delta del Ebro o la Albufera de Valencia, y haría desaparecer un buen número de playas; la llegada de enfermedades tropicales y la irregularidad y violencia climáticas, unidas a algunas de las consecuencias anteriores, afectarían gravemente a la industria turística.

La península Ibérica es un laboratorio ideal para la detectación del cambio climático. España goza de un clima semidesértico, está al borde sur de las borrascas atlánticas. Así como un desplazamiento hacia el norte de unos 500 kms. de la trayectoria de las borrascas (algo que predicen casi todos los modelos de cambio climático) no afectará a los países centroeuropeos, pues están en el centro de la trayectoria, este desplazamiento debe suponer para España recibir la mitad de la precipitación media actual de la Península. Además, esa precipitación estará concentrada en unas pocas semanas, con fenómenos de gran intensidad, lo cual intensificará el déficit hídrico tradicional de sus tierras. A esto tememos que añadir un incremento de las temperaturas, con una evaporación intensificada respecto a la actual ${ }^{132}$.

131. En 25 de abril de 1998, la rotura de la presa de Aznalcóllar (Sevilla), propiedad de la empresa sueca Boliden Apirsa, provocó una riada tóxica de unos cinco millones de metros cúbicos de subproductos químicos contaminantes al río y valle del Guadiamar y al entorno del coto de Doñana, -una de las reservas naturales más grandes de Europa (270.000 hectáreas)-, que afectó gravemente todas las actividades de la zona, causando un prejuicio económico que supera los 18.000 millones de pesetas, según cálculos de la Administración. El desastre ecológico causó un impacto negativo sobre la comercialización "de las actividades agroalimentarias, pesqueras, turísticas [y ecológica] del entorno de Doñana". La Consejería de Medio Ambiente de Andalucía ignoró una serie de denuncias de conservacionistas (CEPA) y técnicos formuladas desde 1994. En diciembre de 2000 una jueza de Sevilla archivó el caso al no encontrar indicios de responsabilidad penal ni el Boliden, ni en Geofisa (filial de Dragados que elaboró el proyecto de construcción de la presa en 1978) ni en la Junta de Andalucía.

132. Cf. A. RUIZ DE ELVIRA, "El cambio climático en España"(1999). 


\begin{tabular}{|c|c|c|c|c|c|c|c|c|c|}
\hline \multicolumn{10}{|c|}{$\begin{array}{c}\text { Evolución de las emisiones de gases de efecto invernadero de } \\
\text { países industrializados respecto al nivel de } 1990 \text { y sus compromisos } \\
\text { en el Protocolo de Kioto. }\end{array}$} \\
\hline & 1991 & 1992 & 1993 & 1994 & 1995 & 1996 & 1997 & 1998 & KIOTO \\
\hline Alemania & $-4,4$ & $-8,8$ & $-10,6$ & $-12,1$ & $-12,4$ & $-11,1$ & $-14,2$ & $-15,9$ & $-21,0$ \\
\hline Australia & $-0,1$ & 0,6 & 1,2 & 1,9 & 5,2 & 7,9 & 10,2 & 15,5 & 8,0 \\
\hline España & 2,3 & 5,3 & 0,5 & 5,8 & 9,4 & 7,6 & 15,8 & 19,4 & 15,0 \\
\hline EE UU & $-0,7$ & 1,0 & 3,0 & 5,0 & 5,7 & 8,9 & 10,2 & 10,3 & $-7,0$ \\
\hline Francia & 4,3 & 1,8 & $-2,8$ & $-3,3$ & $-2,1$ & $-0,2$ & $-1,4$ & 1,0 & 0,0 \\
\hline Italia & 0,0 & $-0,8$ & $-2,3$ & $-3,0$ & 2,2 & 1,5 & 2,2 & 4,2 & $-6,5$ \\
\hline Japón & 1,9 & 3,1 & 1,5 & 7,6 & 8,1 & 9,4 & 9,0 & - & $-6,0$ \\
\hline Polonia & $-4,7$ & $-4,4$ & $-6,4$ & $-4,4$ & $-9,3$ & $-4,9$ & $-7,2$ & $-12,3$ & $-6,0$ \\
\hline Portugal & 3,9 & 8,0 & 5,6 & 7,0 & 13,7 & 9,8 & 12,1 & 17,2 & 27,0 \\
\hline Reino Unido & 0,1 & $-3,1$ & $-6,6$ & $-6,6$ & $-8,2$ & $-5,5$ & $-9,1$ & $-9,5$ & $-12,5$ \\
\hline Rusia & - & - & - & $-29,6$ & $-32,2$ & $-35,8$ & - & $-57,0$ & 0,0 \\
\hline Ucrania & $-14,7$ & $-16,6$ & $-26,2$ & $-37,8$ & $-41,4$ & $-45,6$ & 49,3 & $-50,5$ & 0,0 \\
\hline \multicolumn{10}{|c|}{$\begin{array}{l}\text { Fuente: Secretaría de la Convención Marco de Naciones Unidas } \\
\text { sobre el Cambio Climático. }\end{array}$} \\
\hline
\end{tabular}

En líneas generales, los países industrializados -la mayoría presentes en el cuadro- son responsables del $80 \%$ de las emisiones de gases invernadero.

Las emisiones de los GEI de los países desarrollados han caído un 7,8\% en 1998 (último año para el que se dispone de datos globales oficiales) respecto a 1990. Pero este dato, proporcionado por la Secretaria de la Convención Marco de Naciones Unidas para el Cambio Climático, no debe ser interpretado con triunfalismo, dado que se ajusta a las predicciones realizadas en el pasado. Según esas estimaciones, las emisiones del conjunto de los países industrializados iban a bajar en la primera parte de la década de los noventa, para empezar luego a remontar, de manera que hacia 2010 , si no se toman medidas, esas emisiones habrán aumentado hasta un $18 \%$ respecto a 1990. Esas emisiones han bajado porque los países de Europa del Este han sufrido un derrumbe económico significativo con la consiguiente disminución del consumo de combustibles fósiles. Además de los casos de Rusia y Ucrania, contemplados en el cuadro, Letonia registra una caída de -96\%; y Bulgaria, 
un-48\%. La cifra para el conjunto de esos países, denominados de economía en transición, es de - $50,1 \%$. Además, en el caso de Alemania, con una reducción del 15,9\% (debería reducirlo un 21,0\%), es debido al proceso de desindustrialización sufrido por la antigua Alemania del Este.

Las cifras de la Secretaría de la Convención muestran que, teniendo en cuenta los países más industrializados, excluyendo los de economía en transición, el balance de emisiones en 1998 estaba en 10,8\% por encima del nivel de 1990, frente a la reducción del 5,2\% acordado.

La Unión Europea, que se impuso una reducción del $8 \%$ entre los años 2008 y 2012 respecto a 1990, apenas acaba de estabilizar sus emisiones en 2000; de seguir la misma línea que hasta ahora, apenas conseguirá el 1,4\% en 2010, según las previsiones presentadas por la Comisaria Europea de Medio Ambiente. España, que podía aumentar en ese período sus emisiones de gases de efecto invernadero (GEI) un $17 \%$, de hecho ha tenido un aumento del $19,4 \%$ de $\mathrm{CO}_{2}$ entre 1990 y.1998, el aumento más fuerte en toda la UE.

Podríamos resumir brevemente la situación de los diversos países o grupos, que se reunieron en la Cumbre de La Haya, en los siguientes puntos:

Estados Unidos, la nación más contaminante del planeta, contaminó en 2000 un $11 \%$ más que en 1990. El "grupo Paraguas",-formado, además de EE UU, por Canadá, Japón, Australia y Nueva Zelanda-, no quiso saber nada de sanciones por el incumplimientos de los compromisos de Kioto, y reclamó cierta flexibilidad para hacer frente a esos compromisos.

La "burbuja comunitaria", la Unión Europea, fue la más vanguardista, y aunque no ha cumplido el compromiso de Kioto de reducir sus emisiones de gases causantes del efecto invernadero en un $8 \%$ respecto a los valores de 1990, en 2012 a más tardar, fue a la Haya dispuesta a revalidar su compromiso, y a promover ayudas directas para los países menos desarrollados que encaren sus compromisos medioambientales.

El denominado G-77, un núcleo de 77 países, compuesto por naciones en proceso de desarrollo, -al que se encuentra adherida China-, mantuvo una posición intermedia entre la UE y el grupo paraguas. En todo caso, no quieren que las exigencias medioambientales condicionen su desarrollo económico.

$\mathrm{El}$ "grupo AOSIS" (en sus siglas inglesas), lo componen naciones asentadas en islas ${ }^{133}$, que temen desaparecer bajo las aguas con la crecida de los

133. Los 42 estados miembros de la Alianza de Estados de Pequeñas Islas, ya han levantado su voz para que se recuerde que el aumento del nivel del mar conllevará drásticas pérdidas para sus poblaciones. En Kiribati, un archipiélago del Sur del Pacífico, se están construyendo diques y plantando manglares para proteger las islas del avance del mar. 
mares que se anuncia tras el calentamiento de los casquetes polares. Estuvieron más próximos a las tesis de la UE que los demás.

$\mathrm{Y}$, en fin, existieron otros "lobbys", como la Organización de Países Productores de Petróleo (OPEP), el sector de la energía nuclear ${ }^{134}$ y las grandes ONG ecologistas. La OPEP dijo -como siempre-, que menos emisiones de dióxido de carbono a la atmósfera significaría menos petróleo consumido, es decir, menos ingresos para ellos, y querían que le solucionasen su problema. Las ONG, como Climate Voice, Greenpeace, Amigos de la Tierra, WWF o Rising Tide, dieron la voz de alarma ante los mecanismos de flexibilidad, a los que denominaron "lagunas" o "trampas" 135.

En la Cumbre de La Haya afloraron, pues, las divisiones ya existentes entre los diferentes países y grupos de naciones.

Dos líneas principales acapararon el interés principal de las negociaciones. Por una parte se discutió si se establecían o no limitaciones para los llamados "mecanismos de flexibilidad" (compraventa de emisiones de gases, transferencia tecnológica y "sumideros" de carbono") ${ }^{136}$. La UE defendió que se estableciera un límite a esos mecanismos (en torno a un 50\%), de manera que el esfuerzo que cada país haga para contener las emisiones, se base en medidas de ámbito doméstico. Estados Unidos, sin embargo, se opuso a cualquier limitación y exigió, además, -resucitando la discusión de la conferencia de Kioto-, que los países en vías de desarrollo se comprometieran también en el esfuerzo de limitación de emisiones, del que por ahora estaban excluidos. Los países en desarrollo, por su parte, pretendieron no asumir por

134. El $30 \%$ de la energía consumida anualmente en España, unos 50.000 gigavatios, procede de fuentes nucleares, mientras que un $40 \%$ procede del carbón u otros combustibles fósiles. Así lo aseguran los responsables de la Sociedad Nuclear Española (2000). En el mundo existen unas 430 centrales nucleares. De ellas, 133 de Europa Occidental y unas 40 en la antigua Europa del Este.

135. En la COP6 surgieron otros dos "equipos": el Grupo de Integridad Ambiental (Suiza, México, Corea, Liechtenstein y Mónaco), que a menudo han desempeñado un papel mediador; y el Grupo Central 11 (CG11), que engloba a los países del Este de Europa, excepto Rusia y Ucrania, que van por libre.

136. La implantación de estos "sumideros", mediante la reforestación,-además de las dudas sobre su eficacia ya anotadas- está siendo cuestionada por los "aborígenes" (pueblos indígenas) que viven en las selvas, ya que podrían poner en peligro el sistema de rotación de cultivos y alterar profundamente los bosques. La aceptación del factor "sumidero" supondría, insistía la UE, que los países desarrollados podrían reducir sus emisiones hasta un 3\% menos de lo comprometido en el Protocolo de Kioto. Así, la reducción general podría ser sólo un 2,2\% de las emisiones de 1990, en lugar de un 5,2\%. 
ahora compromisos para contener sus emisiones, mientras que perseguían toda la ayuda financiera y tecnológica posibles ${ }^{137}$.

Aunque los países en desarrollo no estaban obligados por el Protocolo de Kioto, el despegue de la actividad industrial en regiones como el sureste asiático, China o América Latina tiene una traducción directa en un aumento exponencial de sus emisiones de gases contaminantes, por lo que en la Haya se discutió su incorporación a medio o largo plazo a ese convenio.

El papel de los "sumideros de carbono" fue uno de los protagonistas de la negociación: si se considera la reforestación o no como proyecto de desarrollo limpio. Los científicos y expertos no se han puesto de acuerdo acerca de cómo definir los bosques para poder contabilizarlos como sumideros de gases. La "burbuja comunitaria" quería que no se tomaran en cuenta, mientras que EE UU pretendía contar con la ayuda de los sumideros en su balance total de reducción de emisiones.

A pesar de que la Unión Europea mantuvo siempre una postura vanguardista en las medidas de control de los GEI, uno de los puntos en el que la unanimidad europea fue más ardua, se refería a la energía nuclear ${ }^{138}$ como

137. La ayuda financiera de los países industrializados a los en desarrollo, para que tomen medidas ante el cambio climático, asciende a unos 500.000 millones de pesetas en cuatro años (1998-2002).

138. La energía de fisión nuclear es factible tecnológicamente, pero desde el episodio de Chernóbil (26-04-1986) ha bajado enteros. La sombra alarga de este accidente, el único que ha alcanzado la categoría de accidente mayor nuclear, se ha convertido en un lastre para este tipo de energía. Las centrales nucleares en sí no emiten GEI, pero la industria nuclear en su ciclo completo genera emisiones al extraer el mineral, al reprocesarlo, al trasportarlo o al enriquecer el uranio. Existe, además del riesgo de accidentes, el problema de mantener bajo adecuada vigilancia los residuos nucleares, etc. Otra cosa sería la energía de fusión nuclear, que es la que utiliza el Sol y la que ha creado al universo desde el principio. Es limpia pues no genera residuos dañinos. Prácticamente inagotable, porque su combustible, un isótopo de hidrógeno llamado deuterio, se obtiene del agua. Sólo existe un problema: para que la fusión se produzca debe alcanzarse una temperatura de 100 millones de grados. No hay material que resista este calor y los científicos han ideado un sistema de confinamiento magnético que, de momento, necesita 23 millones de vatios para producir 16 millones. Un fracaso. El próximo reto es la construcción del gran Reactor Experimental Termonuclear Internacional (ITER), prevista para el 2002 y en que la tecnología y las investigaciones del Centro de Investigaciones Energéticas, Medioambientales y Tecnológicas (CIEMAT) juegan un importante papel. Costará 3.500 millones de dólares (600.000 mil millones de pesetas) y participarán los países de la Unión Europea, Rusia Japón y Canadá. EE UU se retiró del proyecto hace unos años, lo que ha provocado ciertos retrasos. "Si los plazos se cumplen, y la reciente subida del precio de petróleo (2000) hace prever que sea así, dentro de 20 años tendremos resultados y dentro de 40 empezarán a funcionar las primeras centrales de fusión", opina Carlos Alejaldre, director centro español del Ciemat. ENRESA prevé gestionar unas 296.000 toneladas de materiales en el desmantelamiento de la central nuclear española Valdellòs I. De ellas, 2.000 será residuos radiactivos que espera 


\begin{tabular}{|ll|ll|}
\hline \multicolumn{4}{|c|}{ Producción de energía nuclear } \\
Porcentaje sobre el total de energía \\
producida en 1998 \\
\hline \multicolumn{3}{|c|}{} \\
Lituania & 77 & Suiza & 41 \\
Francia & 76 & Japón & 36 \\
Bélgica & 55 & Hungría & 35 \\
Suecia & 46 & España & 31 \\
Ucrania & 44 & Finlandia & $: 27$ \\
Eslovaquia & 43 & R. Unido & 27 \\
Bulgaria & 41 & EE UU & 19 \\
Corea del sur & 41 & Rusia & 13 \\
& & & \\
& & & \\
\hline
\end{tabular}

mecanismo de flexibilidad. La propuesta fue hecha por Canadá. España se manifestó contraria a incluir a las centrales nucleares ${ }^{139}$, en tanto que no emiten los GEI, en las alternativas tecnológicas contempladas en estos mecanismos. Algunos países, dentro de la UE, como Francia, cuya estrategia energética descansa en la opción nuclear, no descartaron de forma drástica la propuesta.

ubicar en el cementerio de El Cabril (Córdoba). Esta empresa ha firmado un convenio con Eléctrecité de France, responsable del desmantelamiento de la central gemela a la española "Saint Laurent des Faux I", para colaborar en los trabajos de desmantelamiento. Aparte de las cuatro centrales nuclear que Francia tiene en construcción, no hay actualmente en Europa ningún otro proyecto de esa naturaleza. Según datos de la Organización Internacional de la Energía Atómica, reelaborados por el World Information Service on Energy (WISE), en 1998 hubo una disminución de $3.260 \mathrm{~mW}$ de potencia nuclear instalada con respecto a 1997 y, lógicamente, menos reactores en funcionamiento. En 1999, según el WISE, hay sólo 28 reactores en construcción en el mundo: 1 en Argentina, Brasil, Eslovaquia, Irán, Japón y Pakistán; 2 en Chequia, Taiwan y Ucrania; y 4 en Corea del Sur, China, Francia y la India. O sea, sólo 5 en el Primer Mundo industrializado, 4 de los cuales en Francia, que es el último baluarte nuclear energético. Cf. R. FolCH, "¿Vale lo que cuesta?"(1999).

139. En alguna ocasión, el Gobierno español ha prolongado, para algunos sin causa justificada, la vida útil de las centrales nucleares más antiguas. Pero la subida internacional del precio del petróleo, el incremento de la demanda de energía en el sector del transporte y la, cada vez, mayor dependencia energética de la UE, harán muy difícil el cierre de todas la centrales nucleares en ocho países europeos. La energía nuclear representa en la actualidad el $35 \%$ de la producción eléctrica global de la UE frente al $27 \%$ de los combustibles sólidos, al $16 \%$ del gas natural, al $15 \%$ de las energías renovables y al $8 \%$ del petróleo. Bruselas pone un ejemplo de las posibles consecuaencias del abandono prematuro de la 
La otra gran línea de debate se centró en torno a la creación de un fondo adicional para ayudar a los países en desarrollo, al régimen de control y las sanciones que se podrán imponer a los países que no cumplan los compromisos asumidos en el Protocolo de Kioto. En este caso, hubo países que querían sanciones ejemplarizantes y otros, que no las deseaban de ningún tipo.

Los ecologistas, en especial Amigos de la Tierra, Greenpeace y Asociación para la Defensa de la Naturaleza, protagonizaron numerosas manifestaciones y actos de protesta y de información ciudadana ante la cumbre de La Haya, aunque sin tanta presencia mediática como en ocasiones similares. Incluso el delegado norteamericano recibió en la cara el impacto de una tarta de crema que le lanzó un activista durante una conferencia de prensa. Como estamos en la era de la informática, la ONG "Climate Voice" organizó la mayor campaña de recogidas de firmas con once millones de "e-mail" de protesta.

Al final la cumbre del clima de La Haya concluyó, como era de temer, en un rotundo fracaso, camuflado de suspensión temporal, para continuar la "segunda sesión", dentro de medio año (mayo o junio de 2001), de la COP6, "y no perder el impulso negociador". Los países presentes en la convención no pudieron cumplir con el plazo límite que se habían autoimpuesto en la conferencia celebrada en Buenos Aires (1998) para establecer en la cita de La Haya los reglamentos, sin los cuales no puede ponerse en marcha el Protocolo de Kioto (1997). "Ahora sabemos lo difícil que es aplicar el Protocolo de Kioto en reglamentos concretos y políticas", dijo, en nombre de la UE, la ministra francesa de medio ambiente, Dominique Voynet.

La cumbre finalizó, incluso, con la aparición de una cierta división dentro de la Unión Europea y búsqueda de responsabilidades: el representante del Reino Unido culpó a la ministra francesa del fracaso. Francia y Alemania, con ministros de partidos ecologistas, con Portugal, España y Bélgica defendieron posiciones duras en defensa de la integridad medioambiental del

energía nuclear: la decisión de Suecia de cerrar la unidad nuclear de Barsebäck, ha creado un déficit de producción eléctrica de 4.000 millones de $\mathrm{kWh}$ anưales, y un aumento indirecto de las emisiones de dióxido de carbono de 4 millones de toneladas. La UE produce únicamente las mitad de la energía que necesita, y la situación se agravará en los próximos 30 años, cuando la dependencia energética comunitaria será del 70\%. El "libro Verde", adoptado en noviembre de 2000 por la Comisión Europea, propone: acabar con el "derroche" de energía; optar por una verdadera política alternativa para los transportes (revitalizar el uso del ferrocarril, reorganizar los transportes por carretera, racionalizar el uso de vehículos particulares, promoción de medios de transporte ecológicos); y uso de energías renovables que pase del 6 al 12\% desde ahora al año 2010. 
Protocolo de Kioto, ante las devaluadoras propuestas de EE UU140, respecto a los "mecanismos de flexibilidad", cuya aceptación hubiera vaciado de contenido los compromisos adquiridos. La incertidumbre política, en ese momento, respecto al futuro inquilino de la casa Blanca, pudo influir en su postura intransigente en la negociación (se suponía que $\mathrm{Al}$ Gore ${ }^{141}$ estaba más próximo a posturas conservacionistas que los republicanos) ${ }^{142}$. Holanda, presidente de la cumbre, Finlandia (con un gran territorio forestal), Reino Unido ("primos" de EE UU), mantuvieron posturas más acomodaticias o "flexibles". De haberse aceptado las aguadas propuestas norteamericanas pudiera haberse cumplido aquello de que "Tutto sera lo stesso, mentre tutto sera cambiato" 143 .

El documento en el que la organización Greenpeace valoraba la cumbre afirma que "esta reunión será recordada como el momento en que los gobiernos abandonaron la promesa de colaboración global para proteger el planeta Tierra. Los gobiernos deben dejar de actuar como si esto fuera un juego".

El lamentable revés de La Haya, tras dos semanas de debates, hace retroceder la situación a Kioto-1997. Las ayudas al desarrollo, los mecanismos de Kioto, los "sumideros" de carbono y el cumplimiento de sanciones, las cuatro "cestas" en las que el presidente de la cumbre, el holandés Jan Pronk, agrupó las cuestiones en debate, tuvieron la culpa. Una vez más, un conflicto de intereses, ha impedido a los poderosos estar a la altura de las circunstancias. En el ámbito de la concienciación ciudadana, podríamos anotar, como nota de esperanza, el compromiso, llamado "La Apuesta", que jóvenes de 16 países,

140. La postura oficial de la delegación norteamericana resulta menos comprensible cuando en Estados Unidos: el $25 \%$ de los ciudadanos aportan dinero a causas ambientales, y el $60 \%$ se declaran preocupado por el entorno.

141. Al Gore, (La tierra en juego), escribió "estamos iniciando alegremente cambios climáticos que podrían durar siglos (...) Pero, por lo visto no queremos escuchar (...) comportándonos como si un día no fuera a haber niños que hereden nuestro legado. La elección es nuestra". ¿Se trata de una hipocresía? Parece que no. Al Gore es un conservacionista convencido pero, incluso los gobernantes de los países más poderosos, podrían estár atenazados por los tentáculos de las grandes corporaciones. A pocos días de su relevo en la Casa Blanca, Bill Clinton adoptó medidas vanguardistas, como la incorporación de EE UU al Tribunal Penal internacional (TPI) y la orden ejecutiva (no precisa la aprobación de las Cámaras) que prohibe la construcción de carreteras y viviendas y la explotación industrial en 24,3 millones de hectáreas de bosques estadounidenses, un tercio del total. El tratado para la creación del TPI ha sido suscrito por 139 Estados desde su elaboración en Roma en 1998.

142. George W. Bush ha dejado claro, durante su campaña electoral, que jamás firmará el Protocolo de Kioto. Y en sus primeras actuaciones como Presidente, parece que intenta obstaculizar la orden ejecutiva vanguardista de Clinton.

143. T. DI LAMPEDUSA, Il gattopardo, 1995. 
pertenecientes a Amigos de la Tierra Internacional, asumieron en La Haya de reducir sus emisiones personales de $\mathrm{CO}_{2}$ en un $8 \%$ en 8 meses, mediante acciones como gastar menos energía en casa y en el colegio o utilizar el transporte público. Siempre son importantes los signos.

Espero que no nos dejemos contaminar por el fatalismo con que concluía recientemente la revista "Time": "Sólo un optimista, por otra parte mal informado, puede esperar que la humanidad proceda todavía con el plazo suficiente para derrotar los cambios extremos que eviten la tempestad".

\section{LA CUMBRE DEL CLIMA DE BONN (16-27 JULIO-2001)}

La reunión de las Partes de la Convención Marco de Naciones Unidas sobre el Cambio Climático en Bonn, que reanudó los trabajos suspendidos en noviembre de 2000 en la Haya, al no alcanzarse un acuerdo, comenzó con malos augurios. Durante la Administración de Clinton, Estados Unidos fue renuente a ratificar el protocolo a menos que se introdujeran procedimientos que permitieran minimizar los cambios en la industria, el transporte y la energía en un país caracterizado por los bajos precios de los combustibles fósiles y, en consecuencias, por el uso demasiado laxo de este recurso energético. La Administración Bush, por su parte había llevado estas reticencias al límite, con una posición de rechazo a la ratificación. El motivo aducido fue el impacto negativo que la aplicación de tales normas tendrían sobre la economía norteamericana, aunque dice considerar muy seriamente el problema del calentamiento global y estar preparando su propia alternativa. Y la delegación de Japón, había anunciado por boca de su primer ministro, que postergaba su decisión hasta el próximo octubre.

La cumbre tenía como objetivo "no ratificar el Protocolo de Kioto sino aprobar un paquete de medidas que permita iniciar el proceso de ratificaciones de los países que todavía no se han pronunciado para que el acuerdo entre en vigor el año que viene", afirmó el presidente de la cumbre, el holandés Jan Pronk.

Cuatro fueron los grandes bloques temáticos tratados en el encuentro de Bonn: los mecanismos del cumplimiento del Protocolo de Kioto, el sistema de sanciones generales ante el incumplimiento de las normas acordadas, la financiación y transferencia de tecnología a los países en vías de desarrollo y la contabilización de los "sumideros" de carbono. A la cumbre asistieron los representantes de unos 178 países y alrededor de 4.000 personas.

A estos grandes temas se oponía inicialmente el llamado "grupo paraguas", formado por Estados Unidos, Canadá, Australia, Rusia, Nueva 
Zelanda, Noruega, Ucrania, Islandia y Japón. Estos países rechazaban las propuestas por varios motivos: se negaban a aceptar la aprobación de sanciones contra los países que no cumpliesen los acuerdos climáticos. Así, la eficacia real del Protocolo de Kioto quedaba más que diezmada. En el documento de consenso presentado por Pronk se preveía que quien no respetasen las medidas debería reducir sus emisiones en un 30\% más de la cantidad sobrepasada. La Unión Europea cedió "in extremis" para desbloquear las negociaciones. En el acuerdo final se aplaza hasta la primera conferencia de las partes tras la entrada en vigor del protocolo, las decisiones acerca de las medidas legales a tomar en caso de incumplimiento.

Los Países Menos Desarrollados (G-77), por su parte, consideraban que en el acuerdo no se garantizaban suficientemente ayudas para el desarrollo sostenible. Para ganar su apoyo, los Quince acordaron destinar 410 millones de dólares anuales en concepto de apoyos financieros, que se alcanzarían en 2005 con una revisión en 2008, a cargo de la UE más Canadá, Islandia, Suiza y Nueva Zelanda.

Otro punto de fricción lo constituyeron los sumideros,, la masa forestal de cada país, que los gobiernos pueden considerar como crédito a la hora de calcular su obligada disminución de gases contaminantes. A mayor masa, más "margen" de contaminación se permite. Robert Watson, presidente del IPCC, organismo científico de la ONU, y la organización ecologista Amigos de la Tierra (WWF) alertaron sobre la complejidad científica de establecer la capacidad de estos ecosistemas para la absorción de gases de efecto invernadero, del peligro de una utilización generalizada de estas prácticas de reforestación (flora, quizá no autóctona) y de los cambios de uso de la tierra como instrumento político. Los sumideros fueron también, finalmente, aceptados, y con ellos el apoyo de Canadá y Japón.

$Y$ en el último momento, como casi siempre ha sucedido en este tipo de reuniones, la cumbre del clima logró el 23 de Julio de 2001 un histórico acuerdo que permitirá salvar el Protocolo de Kioto. El pacto no es perfecto, pero aleja la amenaza que pendía sobre el protocolo de la anterior cumbre del clima (La Haya), que ha sido superada por el acuerdo conseguido entre la UE, el G-77 + China (que agrupa a más de 130 países en vías de desarrollo), el llamado grupo "paraguas" (Canadá, Japón, Australia, Noriega, Islandia, Nueva Zelanda -excepto EE UU-), y otros grupos regionales de países.

Los representantes de 178 países dejaron solo a Estados Unidos y votaron a favor de un pacto, conseguido tras una maratoniana negociación, que permitirá avanzar en la reducción de gases de efecto invernadero que provocan el calentamiento global. El acuerdo, aplaudido por los ecologistas, pese a 
que sea una versión lavada del Protocolo de Kioto, que rebaja sus expectativas iniciales, recibió un impulso definitivo al reducir la UE sus exigencias para atraer así a Japón, Australia y Canadá, tradicionalmente muy sensibles a las posiciones de Estados Unidos.

Aunque la ausencia de EE UU, el mayor contaminante de gases de efecto invernadero, en términos absolutos y relativos, es grave, porque limita el alcance práctico del acuerdo, Kioto sigue adelante sin los americanos.

El resultado final del pacto, en forma de paquete cerrado, es un documento de 14 páginas que primero aborda la financiación y la ayuda de los países desarrollados a los en vía de desarrollo para hacer frente al cambio climático y sus impactos adversos. Especifica los fondos mundiales para canalizar y gestionar esta ayuda, divide lo que corresponde a la Convención del Clima y al Protocolo de Kioto (para separar la cuenta de Estados Unidos).

El Protocolo recoge unos mecanismos de flexibilidad, que deben ayudar a cumplir los objetivos de reducción de emisiones. Se indica que los países se abstendrán de incluir la energía nuclear en los dos últimos mecanismos. Se especifican condiciones en el uso de estas opciones de flexibilidad, pero no se fijan límites de utilización máxima, como exigía antes la UE para garantizar que los países emprenderían significativos esfuerzos de reducción de emisiones mediante políticas nacionales.

El elemento clave del acuerdo sobre los llamados "sumideros" de carbono -un punto clave de discordia junto a la compraventa de derechos de emisión-, es una tabla en la que se especifica el porcentaje que cada país desarrollado puede descontar de sus emisiones en función de determinadas prácticas forestales (nuevos bosques) y agrícolas (emisiones "negativas"). Si todos utilizasen todo el margen concedido, los cálculos indican que hasta casi un $4 \%$ de reducciones globales acordadas en el Protocolo de Kioto (5,2\%) podrían cumplirse con estos "sumideros". La reducción de emisiones reales en 19982012 estaría poco por encima del 1,2\%. Algunos científicos estiman que las reducciones de emisiones realmente efectivas para que tengan el efecto deseado de mitigación del cambio climático debería acercarse al entorno del $50 \%$, en lugar 'del $5,2 \%$ previsto ${ }^{144}$.

Los grupos defensores del medio ambiente, ecologistas y ONG (Grupo Intergubernamental de Expertos sobre el Cambio Climático (IPCC), Greenpeace, Fondo mundial para la Naturaleza (WWF), Unión de Científicos Preocupados (de EE UU), Amigos de la Tierra Internacional, entre otros)

144. Cf. RiBERA, Alicia, "La cumbre del clima salva el Protocolo de Kioto" (2001). 
han valorado positivamente el acuerdo, aunque destacando las concesiones hechas respecto al documento internacional aprobado en 1977 (Kioto).

El reto de ratificar el instrumento legal de la Convención Marco de Naciones Unidas sobre Cambio Climático para que entre en vigor en 2002, coincidiendo con el décimo aniversario de la Cumbre de Río de Janeiro, se lanzó en Bonn a finales de 1999. La Unión Europea ha hecho bandera de esa fecha bautizada Rio +10 en su compromiso de ratificación. Para que el Protocolo de Kioto entre en vigor debe ser ratificado por al menos 55 países que sumen, al menos, el 55\% de las emisiones de 1999 de los países obligados a reducirlas (los desarrollados). Hasta ahora han firmado el protocolo 84 , y lo han ratificado 36, pero los países desarrollados están muy lejos del mínimo necesario. Se han hecho cálculos de cómo podría ratificarse el protocolo aún en ausencia de EE UU. Con la UE, Rusia y algunos otros países, podría prescindirse matemáticamente también de Japón, pero esto sería inviable políticamente.

La CE tiene intención de proponer la ratificación del protocolo a la UE antes del final del año 2001 para que el proceso pueda completarse en 2002.

En la cita en Marrakech, a la Conferencia de las Partes le quedan todavía cabos por atar en el protocolo. Tendrá, además, que medir el pulso político que realmente arropa al acuerdo. Y, en cualquier caso, los países tendrán que ir desarrollando ya líneas de actuación para el segundo período de cumplimento del Protocolo de Kioto, a partir de 2012, lo que pudiera significar una muestra de "buena globalización".

\section{LA VII CONFERENCIA DE LAS PARTES EN MARRAKECK.-}

Del 29 de octubre al 14 de noviembre de 2001, se celebró en esta ciudad la VII Conferencia de las Partes de la Convención Marco de Naciones Unidas sobre el Cambio Climático (UNFCCC, en sus siglas inglesas).

El objetivo era completar y transcribir en términos legales el acuerdo político alcanzado hacía tres meses en la cumbre de Bonn, esto es, establecer definitivamente las reglas del Protocolo de Kioto para reducir las emisiones de gases de efecto invernadero (GEI), y hacer que ese acuerdo internacional se pusiera en marcha y se iniciara su ratificación por los Estados.

El acuerdo no resultó tan fácil, como se presuponía, por los temas pendientes. Los que han tirado del carro han sido la UE, junto con el G-77 + China (grupo de los países en vías de desarrollo), y los que han puesto más obstáculos (una vez retirado EE UU) ha sido "el grupo paraguas" (Canadá, 
Japón, Australia y Rusia). Y es que la reducción de emisiones de los GEI en los países desarrollados implica medidas complejas en el transporte, el suministro energético, los procesos industriales, la agricultura y hasta los hábitos sociales, de forma que no es sorprendente que algunos de ellos se muestren remisos.

Al final de la negociación, la solución a los escollos se centró en dos. Uno fue referente a la obligación de que los países acepten el régimen de cumplimiento del protocolo (cuyo carácter legal se definirá más adelante) para poder utilizar los llamados mecanismo de flexibilidad, como son la compraventa de emisiones, para cuadrar las cuentas de su contaminación. En este primer escollo la UE se enfrentaba a Japón, y se solventó con una modificación del texto inicial que deja un resquicio para los nipones en caso de que se produzca una contradicción legal con su legislación. El segundo, la insatisfacción de Rusia por los millones de toneladas de dióxido de carbono que se le habían adjudicado en una lista que establece los topes máximos que cada país puede descontarse de sus bosques por el efecto de fijación de ese gas de efecto invernadero. Rusia aceptó cuando sus millones de toneladas de $\mathrm{CO}_{2}$ consentidas subieron de 17 a 33 .

Así, el acuerdo de Bonn concluido en Marraquech, contiene la descripción detallada de cómo tienen que contar los países sus emisiones de GEI, cómo serán penalizados si no los cumplen, cómo contabilizar el efecto de sus bosques y actividades agrícolas, cómo se organizarán los proyectos de reducción de la contaminación, qué ayudas recibirán los países en vías de desarrollo para hacer frente al cambio climático y cómo hay que informar abiertamente acerca de las actividades de cada uno.

Con el acuerdo de la UE, Japón y Rusia las cuentas cuadran por fin: se alcanza el mínimo exigido, tanto por número de países como por el porcentaje mundial de sus emisiones, para que el acuerdo internacional entre en vigor y empiece a funcionar.

Como afirmaba Greenpeace Internacional: "ahora que la arquitectura del Protocolo está hecha, los países no tienen excusa para ratificarlo y ponerlo en funcionamiento". En cuanto a Estados Unidos, "siempre serán bienvenidos".

En septiembre de 2002 se celebrará la cumbre de Johannesburgo sobre Desarrollo Sostenible, llamada Río+ 10. La UE tiene intención de ratificar el Protocolo de Kioto antes de esta conferencia e incluso de que entre en vigor en 2002. 


\section{Conclusiones-hipótesis}

De lo dicho en nuestra reflexión, pudieran deducirse algunas conclusiones-hipótesis, que, en sucesivos estudios, podrían considerarse individualmente para intentar discernir, en profundidad, su plausibilidad científica y su impacto en el amplio tema del medio ambiente:

1) Es evidente que la predicción climática, basada en modelos, no es una ciencia experimental ${ }^{145}$ en el sentido decimonónico, o incluso de principios de nuestro siglo. Pero las grandes cuestiones de la ciencia ya no son experimentables en este sentido. Cuando se descubre una partícula elemental, se descubre en un único laboratorio y con escasas posibilidades de repetición del experimento. La sociedad se interesa por el Big Bang, que por definición no puede ser repetido. Creemos que es necesario introducir el "principio de precaución", por el que los organismos competentes se comprometan a tomar medidas contra cualquier sustancia que pueda causar daños significativos a la salud humana o medioambiental, aunque las evidencias científicas no sean concluyentes. $Y$ aunque parece que en el momento actual no se puede precisar científicamente el tamaño exacto del impacto humano en el clima, se trata de un impacto importante. Los hechos sugieren que el clima terrestre ha sido mucho menos estable de lo que creemos.

2) Aunque pudiera afirmarse que no se ha probado exhaustivamente todavía la relación causa-efecto entre los gases de efecto invernadero y el calentamiento de la tierra, ya que los científicos están jugando con sistemas tan complejos, que tienen dificultades para entenderlos, la mayor parte de los datos disponibles parecen confirmar que los efectos del cambio climático son ya perceptibles y que se deben, en buena medida, a la actividad humana. Habría, pues, que reivindicar el -antes mencionado- "principio de precaución".

3) La ecología que defendemos no es aquella de los "verdes oscuros", "ecologistas coñazo", o "sentimentales de lo espontáneo" basada en la nostalgia, la apología y el culto de un mundo salvaje, virgiliano, bucólico e ideologizado, que piensan que los seres humanos son la plaga de nuestro planeta

145. Steen Malte Willadsen, danés y embriólogo iconoclasta afirma que "el papel de la ciencia experimental es precisamente violar las denominadas leyes de la naturaleza". 
y parecen ignorar que el hombre es naturaleza ${ }^{146}$. O con aquellos otros conservacionistas que defienden que la naturaleza es siempre sabia, y perverso todo intento de modificarla o domeñarla. En nuestra opinión, el medio ambiente adecuado para la vida humana no es ciertamente la selva virgen, sino un ambiente civilizado, esto es, logrado mediante la actuación del ser humano (desarrollo sostenible). Las auténticas necesidades humanas forman parte de los "derechos" de la naturaleza, con el "principio antrópico" incluido, i. e., el puesto singular y único del ser humano en el conjunto de los seres. $\mathrm{El}$ amor por lo creado comienza con el amor por la criatura humana y su vida.

4) Hasta el presente siglo la transformación operada sobre el territorio por cada grupo sucesivo de seres humanos, ha sido sostenible, esto es, la tierra era capaz de regenerar sus recursos naturales a medida que se consumían. Es en los tiempos recientes, a causa de todas las sumas de la tecnología, está surgiendo la realidad del desarrollo insostenible, el que ha hecho saltar las alarmas del planeta. Una sociedad sostenible no significa estancada, fija o inadaptada. Por el contrario, sería una sociedad tendente al desarrollo (aspecto cualitativo) y no sólo al crecimiento (aspecto cuantitativo), capaz de cubrir las necesidades del presente sin comprometer la capacidad de las generaciones futuras.

5) La mayor parte de los informes de organismos fiables, como la ONU, afirman que, con las tendencias actuales en las que el $80 \%$ del consumo energético mundial procede de los combustibles fósiles (petróleo, carbón y gas natural), cuyo uso emite gases dañinos que calientan el planeta (GEI), no se puede sostener ningún modelo de desarrollo económico que sea compatible con la preservación del derredor. Algunos estudios establecen tres líneas de actuación imprescindibles (y rentables): más investigación, más fuentes renovables de energía y más eficiencia en el consumo de casas, empresas y vehículos, que ahora malgastan el $30 \%$ de la energía.

146. La "reconquista del paraiso" tiene un fuerte componente utópico. Pero también ha de reconocerse que eran utopías, y ya se han realizado virtualmente, la desaparición de la esclavitud, o la jornada de 36 horas que preconizaba el propio Tomás Moro, precisamente en el libro "Utopía". Para los defensores de la presión depredadora de la especie humana, la reconquista del paraiso es una posibilidad que, va a venir avalada por la primera ley de la sociología del conocimiento; aquella de que "las cosas se hacen cuando ya no hay más remedio que hacerlas". O si se prefiere decir de otra manera: "Todo tendrá que empeorar todavía, para empezar a mejorar". 
6) Parece que está demostrado que el crecimiento del consumo de energía en los países desarrollados y en proceso de desarrollo es proporcionalmente mucho más rápido, que el descubrimiento y puesta en práctica de nuevas producciones de energías no contaminantes. La energía se utiliza en nuestra civilización fundamentalmente para dos cometidos: para generar electricidad y para el transporte. Para esto último no existe, por ahora, un sustitutivo serio de la gasolina o el gasoil, con prestaciones similares. Sin embargo, para la obtención de electricidad existen más alternativas, aunque siempre debe hablarse de energías complementarias del petróleo y no de verdaderas alternativas.

7) Uno de los mayores problemas medioambientales del próximo siglo pudiera ser la gestión de residuos industriales y orgánicos. Por ello, una de las líneas de investigación transgénica se orienta a la obtención de plantas tratadas genéticamente para que sean capaces de absorber y transformar residuos de metales pesados como el mercurio, mediante un proceso de fitorremediación. Otros desarrollos se encaminan a obtener cultivos capaces de expresar genes que codifican encimas degradantes de compuestos orgánicos nitrogenados o clorados. Los países desarrollados deberían, por una parte, no extender a los en vías de desarrollo, mediante la globalización ${ }^{147}$, los malos hábitos productivos de los ricos; $y$, por otra, hacer que las nuevas tecnologías ${ }^{148}$, menos agresivas con el medio ambiente, no sean su patrimonio exclusivo y se mantengan accesibles para los países subdesarrollados. Y esto, sin pronunciarnos sobre una hipótesis que afirma, que no fue tanto un nivel superior de inteligencia la que hizo desaparecer a los neandertales a manos de los cromañones, sino su superior tecnología. De momento, al menos, no creemos que los robots "sean el siguiente paso en la evolución y acaben desplazando a los seres humanos".

147. P. ORTIZ T., Globalización y conflictos socioambientales. Aproximación comparativa en torno a actores, estrategias y escenarios. Quito 1997.

148. El mercado laboral vive una revolución por la entrada de las nuevas tecnologías de la comunicación y la información, pero este cambio alcanza a una mínima parte de la población mundial (15\%), que vive casi en su totalidad en el mundo desarrollado. La mitad de la humanidad nunca ha hecho una llamada telefónica. Por otra parte, el desempleo registrado oficialmente a finales del año 2000 afectaba a unos 160 millones de trabajadores, 20 millones más que antes de la crisis financiera asiática en 1998. Cf. ORGANIZACIÓN INTERNACIONAL DEL TRABAJO (OIT), "Informe sobre el empleo en el mundo 2001. La vida en el trabajo en la economía de la información" (23-01-2001). 
8) Si bien la naturaleza es un valor en sí misma, no dependiente del beneficio propio del hombre, parece que, teniendo en cuenta las características economicistas de la sociedad del siglo XXI, todos los intentos para frenar los diversos factores contaminantes, deben ir "sólidamente soportados" por aspectos económicos que, de alguna forma, los hagan rentables. La ausencia de factores económicos "contables", en la mayor parte de los casos los conducirían al fracaso. Dos ejemplos prácticos pudieran ser, la inclusión de tareas servícolas en la agricultura ("ahora ya sí algo mío se quema"), y el "negocio" de las eléctricas.

9) Si hasta ahora los problemas relacionados con el medio ambiente habían sido tratados como independientes de otras consideraciones y aspectos, en el próximo siglo los problemas medioambietales informarán la práctica totalidad de las actividades humanas, incluidas la agricultura y la industria. Si los informes medioambientales habían sido considerados hasta ahora como un incordio, una "ralentización" o una consideración romántica de obras y expedientes, es más que probable que sean de absoluta necesidad en los próximos años.

10) En líneas generales, pudiera afirmarse que no se está haciendo todo lo posible y necesario para la protección del medio ambiente, pero sí se están haciendo cosas. Desde los poderes públicos, mediante Libros Blancos, Jornadas u otros medios (incluidas las "condenas ecológicas"), se está intentado potenciar la acción pro-ambiental: en la gestión administrativa, el sistema educativo, la gestión empresarial y la acción social de las entidades ciudadanas, en la búsqueda de una sociedad sostenible. La familia debería ser el principal referente del niño, el agente más importante en las transmisión de los valores medioambientales, por encima incluso de la propia escuela convertida en eco-escuela. Quizá, no haya que crear tanto un pensamiento ecológico, cuanto ecologizar el pensamiento.

11) "Piensa globalmente y actúa localmente" dice una sabia frase ecológica; es necesario actuar de forma ecologista desde las más pequeñas realidades concretas de cada día hasta la más amplias. Aunque los ciudadanos de a pie se hayan mantenido al margen de las grandes decisiones sobre medio ambiente, todos podemos colaborar en su preservación: austeridad en el consumo de energía y recursos; reducción del uso de vehículos particulares; uso moderado de la calefacción y el aire acondicionado; adquisición de útiles para el hogar más eficientes y menos contaminantes; recogida selectiva de basura; exigir a la Administración la promoción de fuentes de energía renovables, 
trato con la tierra, etcétera. Todo ellos bajo la " "norma mínima fundamental de la reciprocidad universalizadora".

12) Considero que una adecuada política medioambiental para la obtención de un desarrollo sostenible pudiera resumirse en los seis puntos que propone Claude Fussler ${ }^{149}$ : "mayor eficiencia en el uso de los recursos materiales, mayor eficiencia en el uso de energía, evaluación del riesgo medioambiental, conservación de recursos (reciclaje), ahorro de recursos energéticos y extensión de la funcionalidad de un producto (un sólo producto, varias funciones"). O "el triángulo de las tres CES: C(onsumo) (de bienes), C(onservación) (de recursos) y C(alidad) (de vida), que serían algo así como la "teoría" de la cuestión. $\mathrm{O}$, incluso, en forma más resumida, el principio de las tres ERRES: reducir, reutilizar y reciclar. Todo ello, complementado con el "Polluter Pays Principle" frente al consumista "usar y tirar".

13) Actualmente, la mayor parte de energías renovables ${ }^{150}$ (hidráulica, solar, eólica, geotérmica y por biomasa), que no emiten gases perjudiciales, o los emiten en cantidades menores, y que ya satisfacen el $14 \%$ del consumo energético mundial, tienen unos costes económicos, que han declinado con rapidez, que las hace competitivas frente a los combustibles fósiles en algunos sectores, y sobre todo en las áreas rurales.

14) Y, para finalizar, una cuestión un tanto utópica y, más bien perteneciente a los que hemos llamado "verdes oscuros". Es cierto que estamos contaminando a marchas forzadas, pero surge la pregunta ¿cuales pueden ser las características de un mundo contaminado? Existen aguas "contaminadas" con ácido sulfúrico, hierro, cobre y zinc, como las del río Tinto en Huelva, que

149. En las asambleas anuales de varias entidades supranacionales, como el FMI y el BIRD, celebradas en Praga, Melbourne o Washington, -como ya lo hemos anotado en la celebrada en Davos-, miles de manifestantes, invocando el "espíritu de Seattle" (EE UU), reclamaban que la globalización beneficiase a los países pobres y no sólo a los desarrollados. Driving Eco Innovation, 1997.

150. Actualmente los arquitectos tienen un reto: la construcción de viviendas "bioclimáticas" o anti cambio climático. Se trata de diseñar viviendas de unos 120 metros cuadrados, que no cuesten más de 20 millones de pesetas, que sean totalmente autosuficientes con energías renovables (solar-eólica), que reciclen el $90 \%$ de sus residuos y que sean susceptibles de monitorizarse. Esto es lo que intenta el proyecto de la Urbanización Bioclimática de Tenerife, organizado mediante concurso por la Unión Internacional de Arquitectos, que ya lleva más de cinco años en marcha. De momento es el único del mundo, costará más de 1.000 millones de pesetas y será financiado íntegramente por el Cabildo Insular de Tenerife y el Instituto Tecnológico de Energías Renovables. 
contienen una biodiversidad extraordinaria: 800 hongos distintos, la mayoría de ellos desconocidos, y 100 algas, además de protozoos y bacterias ${ }^{151}$. Parece probable que el mundo futuro será menos habitables para el hombre y la mayoría de las especias y plantas conocidas, pero, ¿y si perteneciera a lo que, provisionalmente, podríamos denominar proceso de evolución artificial, quizá no tan negativo para otras formas de vida? ${ }^{152}$. Hemos reivindicado el "principio antrópico", pero si no se considerara esta posibilidad, podríamos fácilmente caer en el tan denostado antropocentrismo. Los hechos sugieren que la vida es más resistente de lo que pensamos.

\author{
F. RUBIO CARRACEDO \\ Estudio Teológico Agustiniano \\ Valladolid
}

151. La NASA busca actualmente en el río Tinto las claves de la posible vida en Marte hace más de mil millones de años, dado que las condiciones de vida son muy similares a las que pudieron existir en el planeta rojo. En los 90 kilómetros del cauce del río Tinto, existen elevadas concentraciones de metales pesados, y habitan unas 1.300 especies de seres unicelulares que sobreviven en condiciones de muy extrema acidez $(2,2 \mathrm{de} \mathrm{pH})$ como consecuencia de la actividad minera de la zona. Una veintena de científicos del Centro de Astrobiología (CAB) y de la Agencia Espacial Norteamericana (NASA) pretenden con sus experimentos, crear un robot que, dentro del proyecto "P-Tinto", sea enviado dentro de unos años a Marte para estudiar y determinar el tipo de vida que pudo haber existido allí.

152. Parece que, últimamente, científicos norteamericanos han descubierto una bacteria, la "Deinoccus radiodurans", que puede sobrevivir a 1,5 millones de rads de irradiación gamma -un tipo de radiactividad-, lo que supone que aguanta 3.000 veces la cantidad de radiación que puede matar a un ser humano. Y también sobrevive a altas dosis de radiación ultravioleta, como la procedente del Sol. El proyecto de secuenciación de la "D. Radiodurans", que ha sido realizado por el equipo de Craig Center en el Instituto para la Investigación de Genomas (TIGR) y publicado en Science, está financiado por el Ministerio de Energía de los Estados Unidos. 